\title{
GlobalGAP Certification and International Trade Flows
}

\author{
Dissertation \\ to obtain the $\mathrm{Ph}$. D. degree \\ in the Faculty of Agricultural Sciences, \\ Georg-August-University Göttingen, Germany \\ presented by Amjad Masood \\ Born on 20.03.1983 \\ in Rahim Yar Khan, Pakistan
}

Göttingen, September 2014 
D7

1. Name of referee: Prof. Dr. Bernhard Brümmer

2. Name of co-referee: Dr. Martin Banse

Date of dissertation: 18.09.2014 


\section{Acknowledgements}

I would like to express my deepest gratitude to my first advisor, Prof. Bernhard Brümmer, for his excellent guidance, critical comments and patience, without which my research would not have been successful. I would also like to thank Dr. Martin Banse for guiding my research for the past several years and helping me to develop my thesis with valuable discussions in the doctoral seminars. I am also thankful to Prof. Ludwig Theuvsen for being an excellent committee member. I am deeply indebted to Prof. Matin Qaim, the speaker of GlobalFood, for providing a conducive research atmosphere in the research trading group. I am very grateful to Dr. Sören Prehn, Dr. Janine Pelikan, Dr. Franziska Junker and the GlobalGAP team, including Dr. Gabriele Jahn, Simone Schröder, Yannic Grewe. Finally, I would never have been able to finish my thesis without the help from my colleagues in GlobalFood, friends and family. 


\section{Table of Contents}

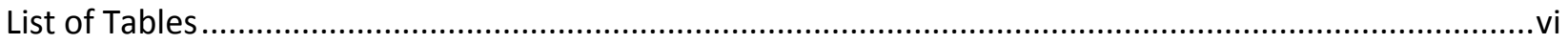

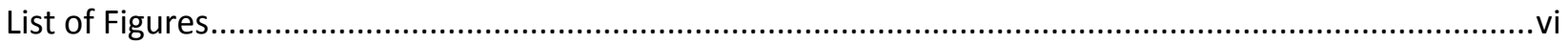

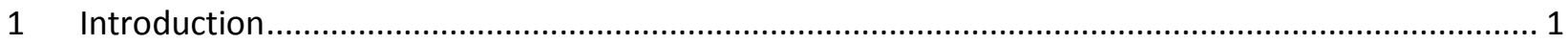

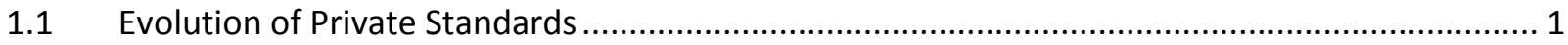

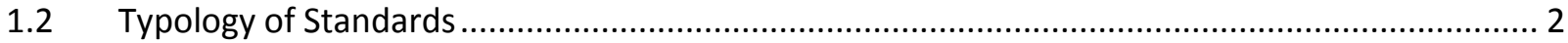

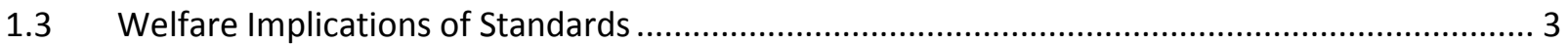

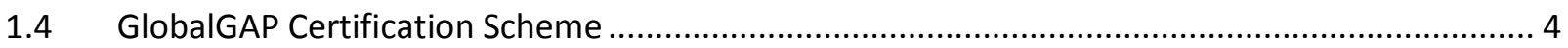

1.5 Objective and Scope of the Research .................................................................................. 7

1.5.1 Determinants of the Diffusion of GlobalGAP ................................................................ 7

1.5.2 Impact of GlobalGAP Certification on EU Banana Imports ................................................ 8

2 Determinants of Worldwide Diffusion of GlobalGAP Certification ................................................ 13

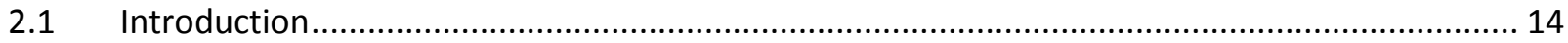

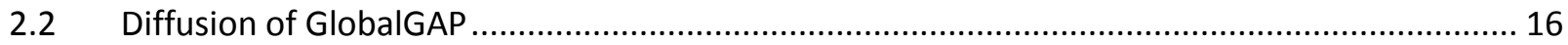

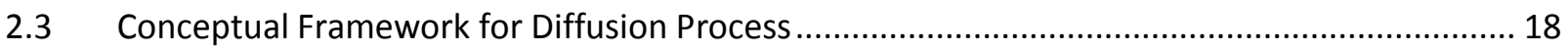

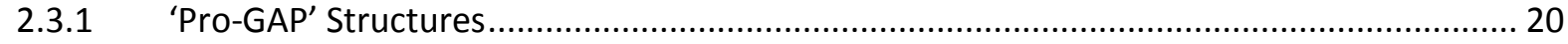

2.3.2 National Macroeconomic Conditions ............................................................................. 21

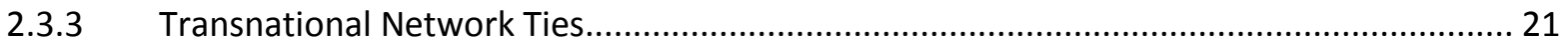

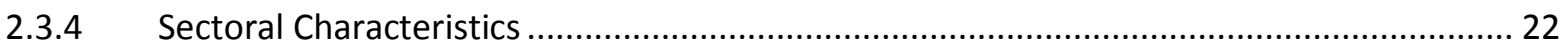

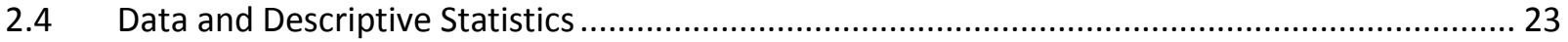

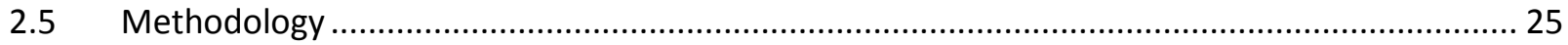

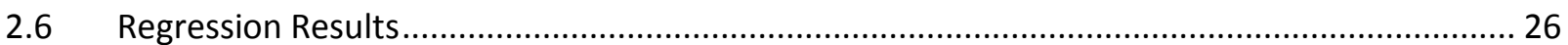

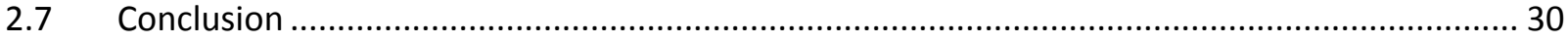

3 Impact of GlobalGAP Certification on EU Banana Imports: A Gravity Modeling Approach................ 33

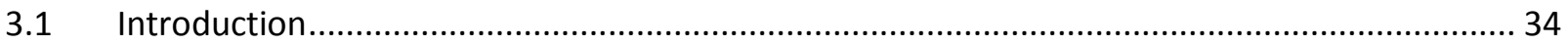

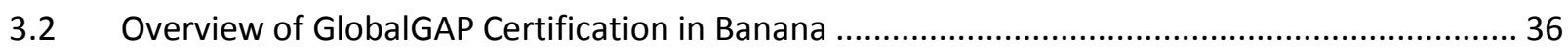

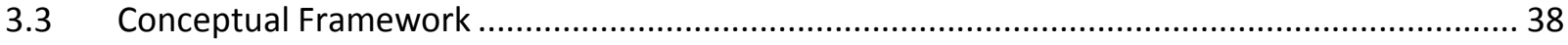

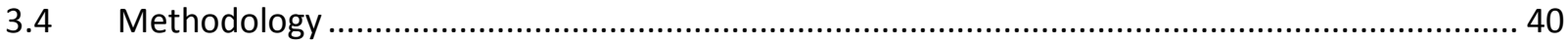

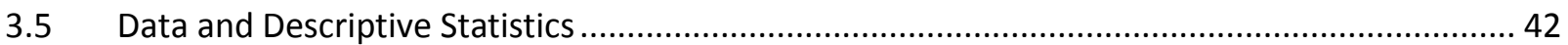




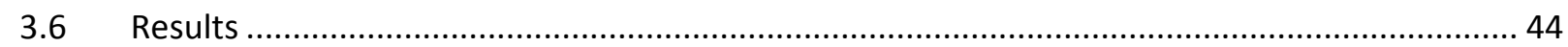

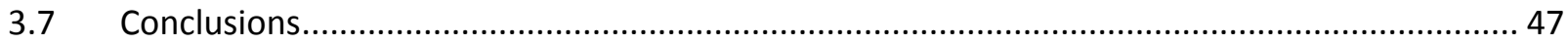

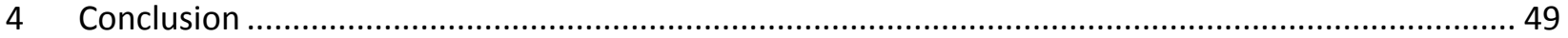

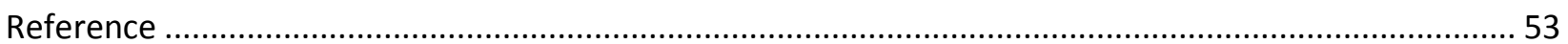

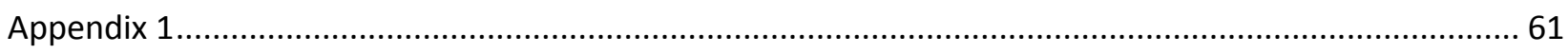

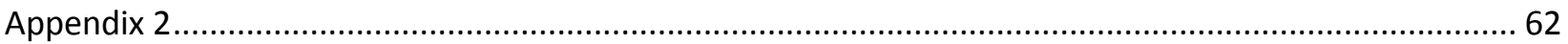

Appendix 3 


\section{List of Tables}

Table 1.1 - Traditional Variables in Gravity Trade Modeling ............................................................... 9

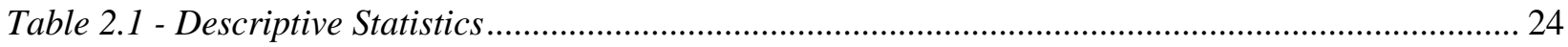

Table 2.2 - Estimation of GlobalGAP Diffusion in Agriculture Sector …................................................. 27

Table 2.3 - Estimation of GlobalGAP Diffusion in Crops Subsector ........................................................ 29

Table 3.1 - Potential Impacts of a Standard on Trade Flow ................................................................... 40

Table 3.2 - Descriptive Statistics ............................................................................................................. 43

Table 3.3 - Impact of Number of GlobalGAP Certified Producers on Value of Banana Imports............... 45

Table 3.4 - Impact of Hectares under GlobalGAP Certification on Value of Banana Imports .................. 46

\section{List of Figures}

Figure 1.1 - The Spread of GlobalGAP over Time ....................................................................................... 5

Figure 1.2 - GlobalGAP Certification across Continents and Agriculture Subsectors .............................. 6

Figure 2.1 - Geographic Variation in the Diffusion of GlobalGAP ......................................................... 18

Figure 2.2 - Conceptual Framework for the Diffusion of GlobalGAP .................................................... 20

Figure 3.1 - GlobalGAP Certification of Bananas around the World ...................................................... 37 


\section{Introduction}

Food trade between agriculture based economies and the developed economies constitutes a significant portion of the global trade. The recent evolution in regulatory practices due to new standards and certification schemes is one of the major factors affecting the pace and pattern of global trade. Due to the biological contents of the agri-food sector, the arena of such regulatory standards is even wider and includes not only the common trade standards, but also regulations such as sanitary and phytosanitary (SPS) measures. This has motivated research on the role of standards in trade flows of the sector. While much of the focus of such economic literature has been on the role of public food safety and quality standards both as policy instruments to promote trade and as non-tariff barriers to trade, it is evident that private standards are playing an increasing role in the governance of agricultural and food supply chains (Henson et al., 2006). Private standards have become a much more integral part of the governance of global agri-food value chains in the last few decades (Henson and Humphrey, 2009).

\subsection{Evolution of Private Standards}

Private standards evolved because of various reasons (Henson and Humphrey, 2009; Jaffee and Henson, 2004). First, with the increase in consumer concern about food safety and quality attributes (Kinsey, 2003); even the industrialized countries have undergone considerable changes in their food regulatory systems. Sometimes, existing regulatory systems are not sufficient to meet such concerns and, as a result, demand for new standards evolves rapidly in many developed countries. Second, with the gradual liberalization of international trade, the agri-food supply chains have been extended far beyond national boundaries. This has complicated the process of coordinating and controlling the transformation and transportation of food stuff around the world (Humphrey, 2008), resulting in a desperate need for new standardization. Furthermore, a shift of responsibility for food safety from public to private sector, most notably in Europe, stimulated, in turn, a motivation for private standards. Such devolution of the state reflects a more general shift to neo-liberalism, encouraging a belief that regulators should work with the private sector rather than see themselves simply as enforcers (Busch et al., 2005).

One valid question in this case is that if there was an increased need for standardization, then why have private standards evolved instead of public standards? The reason could be attributed to the characteristics of private standards (Jaffee and Henson, 2004). For example, private standards go 
beyond the requirements of public standards. In other words, public standards provide the overall structure of standards in general, and private standards fill the voids, in terms of quality and attributes, in public regulations. For example, public standards outline only the elementary parameters of a food safety system while the private standards cover all the necessary detail about not only the end product, but also the whole operationalizing processes, both vertically and horizontally. Increased vertical coverage means how far along the value chain controls are implemented. Alternatively, standards can extend the coverage horizontally over the market structure. Additionally, private standards provide scope of product differentiation, harmonization which cannot be achieved with public standards.

\subsection{Typology of Standards}

The demarcation between public and private standard is not straightforward (Henson and Humphrey, 2010). The term 'private standards' and 'voluntary standards' is frequently used interchangeably (Henson and Humphrey, 2008). Indeed, private standards, developed collectively by private sector actors, are frequently referred to as 'private voluntary standards'. In order to classify the standards, Henson and Humphrey (2008) divided them into public versus private visà-vis mandatory versus voluntary standards, ultimately resulting into four categories: public mandatory, public voluntary, private mandatory and private voluntary.

Private standards developed by coalitions of different actors in the private sector are referred to as 'private voluntary standards' (OECD, 2004). However, Havinga (2008) argued that governance roles in agricultural supply chains are gradually blurring out and private and public standards are emerging in a similar fashion as modes of regulation. Sometimes, private standards are adopted by public regulators and invested with statutory power. In such cases compliance is mandatory and these private standards are then legally mandated private standards. One example of such legally mandated private standards is ISO 9000 in the EU covering CE marking for telecommunications and electronic products.

The extent to which users have freedom of choice regarding compliance to standards can be categorized in three institutional forms: mandatory, de facto and voluntary standards. Standards can be mandatory in a legal sense or required in practice because of the sheer proportion of buyers that require them. Alternatively, standards can be voluntary in the sense that potential 
users can decide whether to comply with them or not. Finally, De Facto mandatory standards arise from an uncoordinated process of market-based competition between the actions of private firms. When a particular set of products or specifications gains market share such that it acquires authority or influence, the set of specifications is then considered as de facto standard. Contemporary agri-food systems are increasingly pervaded by a plethora of private food safety and quality standards that operate alongside regulatory systems and which, although not legally binding in a regulatory sense, can be de facto mandatory for suppliers (Henson and Northen, 1998). Henson and Humphrey (2008) classify the standards into four categories: public mandatory, public voluntary, private mandatory and private voluntary.

In terms of geographic coverage, private standards for individuals vary when compared to to international standards. Individual company standards, which are set by individual firms, predominantly large food retailers, are frequently communicated to consumers as sub-brands on their private label products. Examples of such standards are Nature's Choice, Filières Qualité and Field-to-Fork. Second, standards such as Assured Food Standards and Qualitat Sicherheit, are said to be collective national standards as these are set by collective organizations that operate within the boundaries of individual countries. It is noteworthy that these standards can be inherently national or have international reach. However, a national standard may possibly shift to international domain in the eventuality that the governance structure of the standard is internationalized. Third, collective international standards are defined and adopted by multinational organizations. For example, GlobalGAP, initially created by an international coalition of European retailers, has a much more diversified and internationalized membership. Development and governance of such standards normally involve combinations of public, private and NGO actors (Abbott and Snidal, 2008) in differing proportions. The Forest Stewardship Council, for instance, has stakeholders in various countries and it upholds parity between northern and southern stakeholders (Dingworth, 2008).

\subsection{Welfare Implications of Standards}

There is a growing body of empirical literature that analyzes the welfare role played by standards, both public and private, and feeds the debate on "standards-as-barriers" and "standards-as catalysts". 
Private standards may have several effects on export competitiveness and performance of developing countries. Standards reduce information asymmetry between exporters and importers about quality and production technology which then improves the importer's market share, export volume, monitoring efficiency and price premium (Darby and Karni, 1973; Nelson, 1970; Graffham et al., 2009). Some studies have indicated how comprehensive value chain system between large food companies and developing country producers could be developed as a result of increasing numbers of food standards (e.g. Gulati et al., 2007; Jaffee, 2003; Minten et al., 2006; Swinnen, 2005). Recent empirical studies have demonstrated beneficial effects, of participation in schemes which involve contractual production, in terms of productivity gains, increased household income, reduced volatility, technology and employment spillovers (Dries and Swinnen, 2004); for small dairy farmers (Maertens and Swinnen, 2009); for Senegalese horticulture export and (Minten et al., 2006).

On the other hand, some studies argued that standards act as new non-tariff barriers diminishing the export opportunities for those facing difficulties to comply (Augier et al., 2005; Brenton and Manchin, 2002; Ferrantino, 2006). Standards also pose new financial constraints, such as increased monitoring costs, certification costs with small exporters (Maertens et al., 2007) and small farmers leaving the market (Gibbon, 2003; Reardon and Barrett, 2000; Reardon et al., 1999).

Evidence on the welfare implications of standards is therefore ambiguous, and whether they are trade enhancing or restricting remains an open question.

In this thesis we attempt to provide an overview of the aspects associated with the increasing role of private food safety standards in global agri-food value chains, with a particular focus on one specific private standard, namely GlobalGAP. In the following sections we provide a brief overview of GlobalGAP and then briefly summarize specific research questions we addressed in the thesis.

\subsection{GlobalGAP Certification Scheme}

GlobalGAP, a pre-farm-gate standard, has established itself as a key reference for Good Agricultural Practice (GAP) in the global market place, especially in countries including Austria, Chile, Denmark, France, Germany, Japan, Kenya, Mexico, New Zealand, Spain, and the UK, 
where GlobalGAP has been incorporated into their domestic GAP standards in the form of public-private joint ventures (Mitchell, 2008). GlobalGAP started back in 1997 as EurepGAP, an initiative by retailers belonging to the Euro-Retailer Produce Working Group ${ }^{1}$. In 2001, EurepGAP receives the first ISO 65 accreditation for Fruit and Vegetables and started granting its first farmer certificates. With growing concerns regarding product safety, environmental impact and health, the standard spread throughout Europe and beyond over the following years (GlobalGAP, 2013).

Driven by the impacts of globalization, a growing number of producers and retailers around the globe collaborated, gaining the European organization global significance. In 2007, EurepGAP was renamed GlobalGAP. While GlobalGAP was originally conceived by a group of supermarkets and continues to be viewed generally as a food retailer protocol, the organization quickly moved to re-conceptualize itself in 2001 as 'an equal partnership of agricultural producers and retailers' (Bain, 2010). Later, the membership scope was broadened to include organizations directly involved in growing and trading food products, certification bodies, consulting companies, agri-chemical companies, and their associations. While GlobalGAP incorporates standards for worker health and safety and the environment, the focus of GlobalGAP is food safety. GlobalGAP covers certification of all farming activities and farm inputs until the product leaves the farm.

Figure 1.1 - The Spread of GlobalGAP over Time

\section{Number of Producers under \\ Certification Scheme}

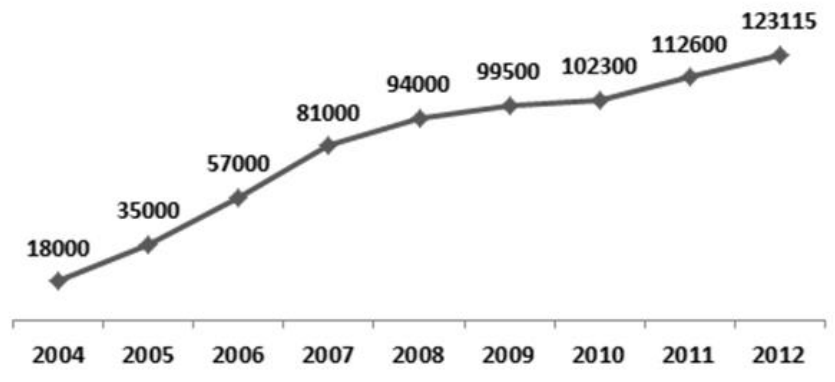

Source: GlobalGAP, 2012

\footnotetext{
${ }^{1}$ This group includes retail giants Tesco, Safeway, Sainsbury's, and Marks \& Spencer, together with Dutch retailer Royal Ahold
} 
In recent years, GlobalGAP has been growing rapidly. The standard possess a network of 1400 trained inspectors and auditors working for 142 accredited certification bodies certifying 409 agricultural products in 112 countries (GlobalGAP, 2012). Figure 1.1 illustrates the considerable enhancement in the magnitude of diffusion of GlobalGAP in terms of number of producers. As shown in figure 1.2, in terms of geographic areas, GlobalGAP has been extending across the world; however, Europe constitutes 74 percent, the largest portion, of GlobalGAP coverage. The figure also explains the share of GlobalGAP coverage across agricultural subsectors. GlobalGAP membership of livestock suppliers constitutes 8 percent, aquaculture 22 percent while the majority of GlobalGAP suppliers are crop growers with a share of 70 percent. Within the crops subsector, a major focus of GlobalGAP certification is fruits and vegetables (Appendix 1).

\section{Figure 1.2 - GlobalGAP Certification across Continents and Agriculture Subsectors}
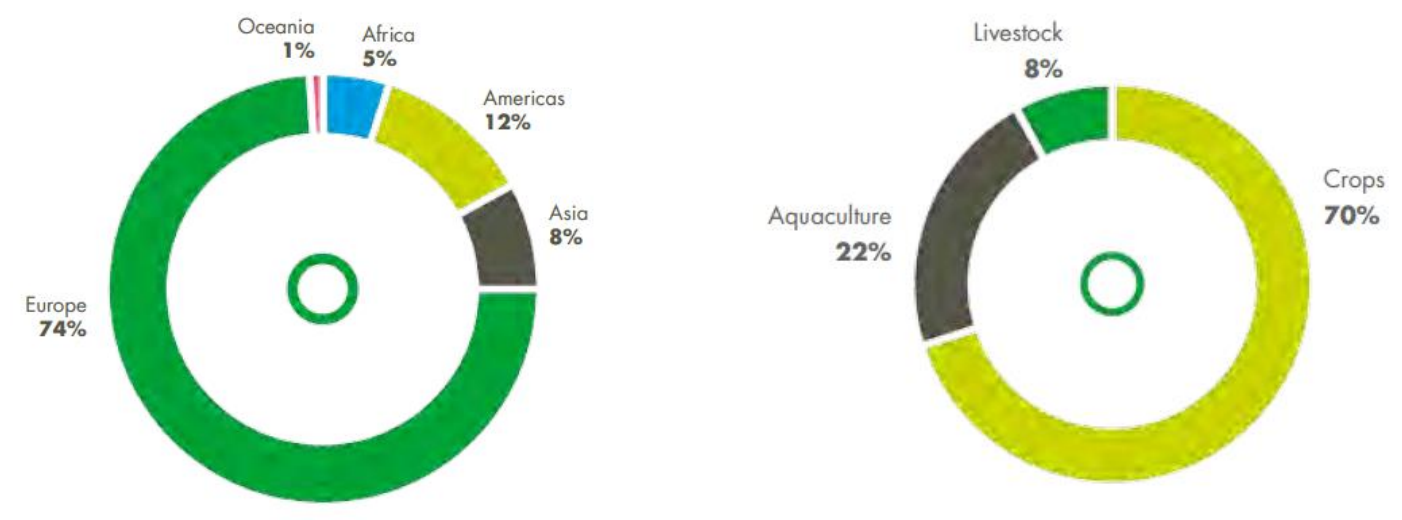

Source: GlobalGAP, 2012

On its welfare implications, GlobalGAP encompasses issues related to the high cost of compliance mainly borne by small farmers (Asfaw et al., 2010b; Chemnitz, 2007; Mausch et al., 2009). For instance, whether or not farmers receive price premiums from GlobalGAP adoption is a debated issue. Kariuki et al. (2012) found evidence of the existence of price premiums, while, Ouma (2010) and Thiagarajan et al. (2005) provides evidence against no existence of price premiums. At the same time, the literature points at benefits for those who were successfully certified, including higher incomes, improved bargaining power, more secured relations with 
their trade partners, and continued access to export markets (Asfaw et al., 2010a). Finally, there is also evidence of indirect benefits from GlobalGAP, such as increased employment (Maertens \& Swinnen, 2009) and improved health outcomes among farmers (Asfaw et al., 2010a).

\subsection{Objective and Scope of the Research}

The empirical evidence from private standards such as GlobalGAP is informative but needs to be complemented by more macro level studies. Our research focuses more on macro level factors and identifies the variables causing private GlobalGAP diffusion and its impact on trade. The specific issues addressed by the thesis are as follows:

\subsubsection{Determinants of the Diffusion of GlobalGAP}

Certification schemes such as ISO, British Retailers Consortium and GlobalGAP are seen as organizational innovations ${ }^{2}$. Over the past decades, there have been studies on the diffusion of innovation (e.g. Ryan and Gross, 1943; Fisher and Pry, 1971). There is a wide range of recent literature mostly focusing on ISO standards. Some studies analyze different factors that affect the adopters' motivations (e.g. Bansal and Hunter, 2003; Boiral, 2007; Gavronski et al., 2008; Prajogo et al., 2012). The perceived benefits from the adoption of a standard are a major factor of motivation. There are several studies which prove potential benefits associated with the adoption of a standard. These benefits include reduction in the consumption of resources and improved competency (Bansal and Bogner, 2002; Melnyk et al., 2002). Other studies (e.g. Terziovski et al., 2003; Casadesús and Karapetrovic, 2005) indicate that standardization helps improving operational performance and results in greater customer satisfaction. There are a number of studies that analyze global diffusion of ISO standards (Corbett and Kirsch, 2001; Viadiu et al., 2006; Albuquerque et al., 2007; Nishitani, 2010; Corbett and Kirsch, 2001) and establish a positive relationship between ISO 14001 certification and export propensity and environmental attitudes. Potoski and Prakash (2004) find that there is a direct relationship between the level of macroeconomic development of a country and the intensity of ISO certification. Neumayer and

\footnotetext{
${ }^{2}$ Alänge et al. (1998) offer detailed review and comparison of technical and organizational innovations. There are two major categories of innovations, namely technical and organizational innovations. Technical innovations refer to a new process and new products or services, whereas organizational innovations involve new procedures, policies and organizational forms.
} 
Perkins (2004) is another study with similar findings. Alburquerque et al. (2007) finds that bilateral trade, geographical proximity and cultural similarity affect diffusion process.

There have been a number of studies on GlobalGAP, a standard which is clearly relevant to the agricultural sector. Some studies analyze farm level adoption of GlobalGAP for specific countries. For example, Kleinwechter and Grethe (2006) have studied the adoption of the EurepGAP standard in the mango export sector in Peru in 2004-2005. Asfaw et al. (2009) analyzed GlobalGAP adoption by small-scale farmers in Kenya. Reardon et al. (2004) point out the need for additional investment in terms of upgrading production technologies and procedures in order to comply with the standard. Some studies such as Chemnitz (2007) and Okello (2005) analyze various factors including access to credit, capital endowment and farm size, all of which can affect the adoption process. Another study by Kersting and Wollni (2012) investigated the role of public private partnership in the adoption of the GlobalGAP standard by small farmers in Thailand.

To our knowledge, only one study looks at global diffusion of GlobalGAP: Herzfeld et al. (2011) analyzed the adoption of BRC food and GlobalGAP standards. We use a panel for five years (2008 to 2012) for 170 FAO member countries to analyze GlobalGAP diffusion in the agriculture sector as a whole as well as in the crops subsector. For estimation, the Heckman two-stage model is applied using the number of GlobalGAP certified producers as well as the hectares of area harvested under GlobalGAP as dependent variables

\subsubsection{Impact of GlobalGAP Certification on EU Banana Imports}

There is a growing body of empirical literature, central to the debate on "standards-as-barriers" and "standards-as-catalysts" which analyzes the relationship between standards and trade flows. The largest part of the evidence comes from trade models, such as gravity models, that estimate the impact of standards, primarily public standards, on international trade flows. In our analysis we take the case of a private standard, namely GlobalGAP, and investigate its impact on EU banana imports using a gravity modeling framework.

Tinbergen (1962) used the gravity trade model to explain trade flows for the first time. It has been recognized as one of the most successful empirical models in economics. In fact, the gravity equation enables us to explain different types of flows such as migration, commuting, tourism, 
and commodity shipping. Ricardian and Heckscher-Ohlin trade models have been two prominent approaches to explain trade. Ricardian theory of comparative advantage explains bilateral trade on the basis of technological differences across countries. Unlike the Ricardian approach where factor endowment is not considered directly, the estimation of trade patterns in the HeckscherOhlin model is based on the difference in factor endowments among different countries. In order to explain the magnitude of trade, several variables have traditionally been used in the gravity equation, including country GDP and population, distance between trading partners, commonality of language, border sharing and colonial relationship of the country pair. In Table 1.1, we list these variables with their expected sign of impact on trade flows.

\section{Table 1.1 - Traditional Variables in Gravity Trade Modeling}

\begin{tabular}{lcl}
\hline Variable & Impact & Theoretical reasoning \\
\hline Exporter GDP & + & The larger the economic scale, the bigger the potential export supply \\
Importer GDP & + & $\begin{array}{l}\text { The larger the economic scale, the bigger the potential import demand } \\
\text { ability }\end{array}$ \\
$\begin{array}{l}\text { Exporter } \\
\text { population }\end{array}$ & - & The larger the population, larger domestic demand, the lesser exports \\
$\begin{array}{l}\text { Importer } \\
\text { population }\end{array}$ & + & The larger the population, the bigger potential import demand \\
$\begin{array}{l}\text { Distance } \\
\text { Common } \\
\text { language }\end{array}$ & + & The larger the distance, the higher the transaction cost, hence lesser trade \\
Colonial tie & + & Common language facilitates trade growth \\
Shared border & + & Mutual relationships facilitate trade growth \\
\hline
\end{tabular}

Anderson (1979) was the first attempt to provide a theoretical basis for the gravity trade model. The model makes use of the concept of an Armington assumption which says that products traded internationally are differentiated by country of origin. This means that the same breed of banana produced in Cameroon and Columbia can be differentiated by the consumer in an importing country. It implies that, regardless of price, a country will consume at least some of every good 
from every country. This concept has now been a standard approach to model demand functions in computable general equilibrium models. Bergstrand (1985) shows how the gravity model can be created as a direct implication of a trade model based on monopolistic competition where consumer preference for a variety of goods drives trade of differentiated goods among identical countries. Deardorff (1998) is another work to provide theoretical background to the gravity equation where it is showed that bilateral trade can be explained theoretically on the basis of traditional factor proportions. Anderson and van Wincoop (2003) offer a very significant contribution toward the present day concept of gravity trade estimation. They argued that it needs to consider relative trade costs, not absolute trade costs, for an appropriate specification of the gravity model. In this way, trade flows between two countries can be calculated on the basis of exporter's outward multilateral resistance and the importers inward multilateral resistance

Gravity trade models have been widely uses to analyze the impact of standards on international trade flows. Applying the gravity equation with an OLS estimator, Otsuki et al. (2001) analyzed the impact of new EU standards for aflatoxins on food exports from African countries. For this, their estimation considers data from 15 European and 9 African countries. Wilson and Otsuki (2004) applied a similar gravity model using regulatory data from 11 OECD importing countries and trade data from 19 exporting countries. They examined the impact of the Maximum Residual Limit (MRL) of pesticides on trade. Their results suggest that a $1 \%$ increase in regulatory stringency leads to a decrease in banana trade of $1.63 \%$. This significant impact on trade policy has implications for developing countries who continue to rely on exports of agricultural commodities such as bananas.

Using a Panel model for 1990 to 2004, Anders and Caswell (2009) analyzed the impact of Hazard Analysis Critical Control Points (HACCP) implementation on U.S. seafood imports. The results show a significantly negative impact after the introduction of HACCP on overall imports from the top thirty-three suppliers. In the individual country-level analysis, they find that regardless of development status, leading seafood exporters generally experienced a positive HACCP effect, while most other smaller trading partners faced a negative effect.

Xiong and Beghin (2011) examined the impact of SPS on agricultural trade in OECD countries. They used an econometric approach to disentangle the demand-enhancing effect and the trade cost effect of a trade regulatory policy. Wei et al. (2012) estimate the impact of food safety 
standards indicated by Sanitary and Phytosanitary (SPS) measures including the MRL of pesticides on tea exports from China. Their results indicate that the tea exports face a significant restrictive impact from the importing countries' safety regulations. Ferro et al. (2013) analyze the impact of product standards on agricultural exports from developing countries. They find a lower probability of observing trade due to more stringent standards. Furthermore, they find that stringent standards mostly increase fixed costs. So once firms enter the market, standards do not impact the level of exports.

As discussed before, standards could either be catalysts or impediments to international trade. However, most of the work so far has focused on public regulation. The impact of increasing growing private standards such as the British Retailers Consortium and GlobalGAP is almost unexplored. A major reason could be the unavailability of data on these private standards. We examine the impact of GlobalGAP in agrifood trade. So far, on the impact of standards on trade volume, the literature has mostly been catering for public food safety and quality standards and very little has been done in the area of private standards. Our study takes the case of private standards and examines the impact of GlobalGAP certification intensity on the banana imports of the European Union. To this end, we use highly disaggregated data on banana imports from 74 countries to the European Union (EU) using a gravity modeling framework. 


\title{
2 Determinants of Worldwide Diffusion of GlobalGAP Certification
}

\author{
Amjad Masood, Bernhard Brümmer \\ Department of Agricultural Economics and Rural Development, \\ University of Göttingen, Germany
}

\begin{abstract}
GlobalGAP is an important private standard in the food sector. However, geographic diffusion of GlobalGAP is uneven across the world. We use a panel from 2008 to 2012 for 170 FAO member countries to analyze GlobalGAP diffusion in the agricultural sector as a whole as well as in the crops subsector. So far, studies on standards have mostly dealt with farm level data and a select few consider the case of macroeconomic determinants of diffusion, although only in the case of public standards. Conversely, we consider the case of a private standard, namely GlobalGAP and estimate the macroeconomic determinants of GlobalGAP diffusion. For estimation, a Heckman two-stage model is applied using the number of GlobalGAP certified producers as well as the hectares of area harvested under GlobalGAP as dependent variables. We analyze the impact of network ties and historical relations among countries, and various macroeconomic conditions prevailing in courtiers on diffusion of certification. The study finds that diffusion is positively related to common language, presence of domestic auditing facility and better infrastructure. We also find that countries with higher relative proportions of fruits and vegetables in the agriculture sector, and with more exports of fruits and vegetables to the EU states have higher coverage of GlobalGAP.
\end{abstract}

Keywords: Standards, Food quality, Diffusion, Organizational innovation, GlobalGAP 


\subsection{Introduction}

Private food standards are now increasingly becoming a critical component of governance of global agri-food value chains. Wholesalers in developing countries are asked to fulfill strict standard requirements and the dynamics of these policies are transmitted along the supply chain to producers. By complying with the requirements of the standard, small farmers in developing countries could potentially gain access to global value chains, which in turn creates new economic opportunities for them. In this paper we attempt to understand whether adoption and diffusion of these standards is entirely random or if there are factors contributing to this.

Analysis of adoption and diffusion of private food standards is crucial for welfare implications (Von Braun, 2003). Two relevant concerns regarding this are (1) standards create inequality among farmers who are able and who are not able to comply with the standard requirements. Those who cannot comply are eventually driven out of the export markets (Reardon et al., 2001; Ponte, 2008; Campbell, 2005). (2) Standards play a crucial role in integrating small holders to the international value chains which does not only promote economic welfare of the certified producers, but additionally creates spillover effects in terms of further income and employment opportunities in the developing countries (Maertens and Swinnen, 2009; Minten et al., 2009; Henson and Humphrey, 2010). This justifies why we should understand diffusion of food standards. Countries vary from each other with respect to their geographical conditions, institutional structures and level of economic development; therefore, the capacity as well as pace of adoption of these standards also vary across the countries. In this study we attempt to identify the factors that have been contributing to the varying standard adoption rate.

There is a large body of literature that has been contributing to the understanding of standard adoption. For example, Kleinwechter and Grethe (2006) have studied the adoption of the EurepGAP standard in the mango export sector in Peru in 2004-2005. Asfaw et al. (2009) and Kersting and Wollni (2012) analyzed GlobalGAP adoption by small-scale farmers in Kenya and Thailand respectively. These studies focus mainly on firm level data and identified factors, such as household characteristics, cost to comply, private-public partnership and support from donor (Kertsting and Wollni, 2012) as crucial determinants of standard adoption. Most of these factors can be managed either by farmers or the retailer. However, the country level factors, though important for standard adoption and diffusion, are beyond the control of farmers as well as 
retailers (Herzfeld et al., 2011). Other authors focused on diffusion of ISO standards at the macroscopic level, such as Corbett and Kirsch (2001), Potoski and Prakash (2004), Neumayer and Perkins (2005), King et al. (2005), Darnall and Edwards (2006), Alburquerque et al. (2007), and Perkins and Neumayer (2012).

In this paper, we take the stand that besides firm level characteristics, there could be a number of country specific characteristics which are crucial in terms of diffusion of private standards. Investigating these country specific factors, such as macro-economic conditions, existing infrastructure and adoption of technologies, could be of huge relevance to the understanding of the cross national differences in standard diffusion (Rogers, 2003). Our paper attempts to fulfill the gap in the literature by studying GlobalGAP certification as one of the case studies on standard diffusion. GlobalGAP is a private food standard which is important for exporting to EU countries. Despite the spread of GlobalGAP in a number of countries, the magnitude of certification remains highly uneven throughout the world (see appendix 2).

We argue aside from firm characteristics, other macroeconomic characteristics have also been contributing to the issue, including geographical preconditions, variation in economic development and institutional structure. In this study, we investigate these factors and attempt to identify the ones which are crucial for GlobalGAP diffusion. Using two step Heckman modeling, we primarily estimate the macro determinants of GlobalGAP diffusion in the agricultural sector. The specific contributions of this study are as follows: First, unlike other studies that mainly focus on firm characteristics, we explore the impact of macro level factors of GlobalGAP diffusion. To the best of our knowledge, the only study that stands close to ours is by Herzfeld et al. (2011) which analyze adoption of BRC food standards and GlobalGAP using a count data model in a cross section setting. We, on the other hand, use a panel data for the five year period 2008 to 2012 for 170 FAO member countries to analyze GlobalGAP diffusion. Second, our study uses multiple measures of diffusion. They use the count of certified producer as the dependent variable, if the country has at least one certified producer in agriculture. In addition to the number of certified producers in agriculture that have crop, aquaculture and livestock production, we additionally take a specific look at the crop sector which accounts for $72 \%$ certification in GlobalGAP (GlobalGAP, 2011) of the whole agriculture sector. While analyzing the crop sector in addition to the number of certified producers, we also used land coverage under the 
GlobalGAP scheme to capture diffusion ${ }^{3}$. We consider land coverage as a better measure of diffusion than the number of certified producers, primarily because a larger number of certified producers in a country does not necessarily indicate higher diffusion because of variability in landholding across farmers. Finally, we argue that our study contributes to the existing literature in terms of implications with regards to the further redistribution of GlobalGAP markets worldwide. By identifying the factors that have positive (negative) impact on GlobalGAP diffusion, our study would help to design policies targeting adoption of new standards and explore the markets that have still not been explored by GlobalGAP.

The rest of the paper is organized as follows. Section 2.2 provides details on various aspects of GlobalGAP. Section 2.3 describes the conceptual framework for addressing the determinants of GlobalGAP diffusion. Data and descriptive statistics are described in Section 2.4. Methodology is described in Section 2.5, followed by the results and interpretation of our analysis in section 2.6. Section 2.7 concludes the study.

\subsection{Diffusion of GlobalGAP}

Predominantly, the literature employs the terms 'private standards' and 'voluntary standards' interchangeably (Henson and Humphrey, 2008). Private standards developed by coalitions of different actors in the private sector are referred to as 'private voluntary standards' (OECD, 2004). However, Havinga (2008) argued that governance roles in agricultural supply chains are gradually blurring out, and private and public standards are emerging in a similar fashion as modes of regulation. Sometimes, private standards are adopted by public regulators and invested with statutory power. In such cases, compliance is mandatory and these private standards are then legally mandated private standards. One example of such legally mandated private standards is ISO 9000 in the EU, covering CE marking for telecommunications and electronic products.

Private standards differ from each other in terms of freedom of compliance: some standards are voluntary while others are mandatory or de facto mandatory. Private food standards also vary in terms of their geographic scope. Some standards are individual such as Nature's Choice (Tesco), Filières Qualité and Field-to-Fork. Some are collective national standards e.g. Assured Food

\footnotetext{
${ }^{3}$ Analyzing land coverage is not carried out for the whole agriculture sector as it is only relevant for the crops sector;aquaculture and livestock production do not require land.
} 
Standards, Qualitat Sicherheit and Farm Assured British Beef and Lamb. There are still some other collective standards with international scope such as the International Food Standard, Marine Stewardship Council, Forest Stewardship Council and GlobalGAP. GlobalGAP is among the leading certification schemes in the food sector. Initially started as EUREPGAP in 1997 by retailers associated with the Euro-Retailer Produce Working Group (EUREP), it was renamed GlobalGAP in 2007 as more and more producers and retailers around the globe got connected over time. Primarily a pre-farm-gate process standard, GlobalGAP has increasingly been considered as a key reference for Good Agricultural Practice (GAP) for worldwide food safety affairs. In countries including Austria, Chile, Denmark, France, Germany, Japan, Kenya, Mexico, New Zealand, Spain, and the UK, GlobalGAP has been incorporated into domestic GAP standards, usually in the form of public-private joint ventures (Mitchell, 2008).

In several countries there are local standardization schemes such as Chile GAP and Thai GAP. The GlobalGAP standardization scheme involves a benchmarking procedure ${ }^{4}$ to include those farmers complying with local schemes wherever the compliance level is equivalent to that required by GlobalGAP. There are four options for GlobalGAP certification. Option-1 means GlobalGAP certification for an individual farmer. Option-2 is GlobalGAP certification for individual farmers following the benchmarking mechanism. Similarly, Option-3 and Option-4 mean group certification for GlobalGAP and benchmarked local schemes, respectively. (GlobalGAP, 2013).

GlobalGAP has been spreading worldwide rapidly. In 2004, there were almost 18000 certified producers under the standard (then EurepGAP); that figure had grown to about 123000 by 2012 (see Figure 1.1). The scheme possesses a network of 1400 trained inspectors and auditors working for 142 accredited certification bodies certifying 409 agricultural products in 112 countries (GlobalGAP, 2012). However, there is huge geographic variation in the diffusion of GlobalGAP (see Figure 2.1). Some countries e.g. Chile, Italy, Kenya, Peru, South Africa, have relatively higher coverage of the standardization scheme. On the other hand, there are countries, e.g., Jamaica, Venezuela, Indonesia, with only one or a few certificates of GlobalGAP standard.

\footnotetext{
${ }^{4}$ The main objective of the benchmarking process is to avoid duplicity of the compliance procedure. Hence, the benchmarking procedure follows a 'one auditor through the farm gate' principle. Synchronizing the requirements of different schemes and standards in this way trims down the costs, administration, time, efforts, and labels international recognition, benefitting the producers, suppliers and retailers.
} 
Figure 2.1 - Geographic Variation in the Diffusion of GlobalGAP

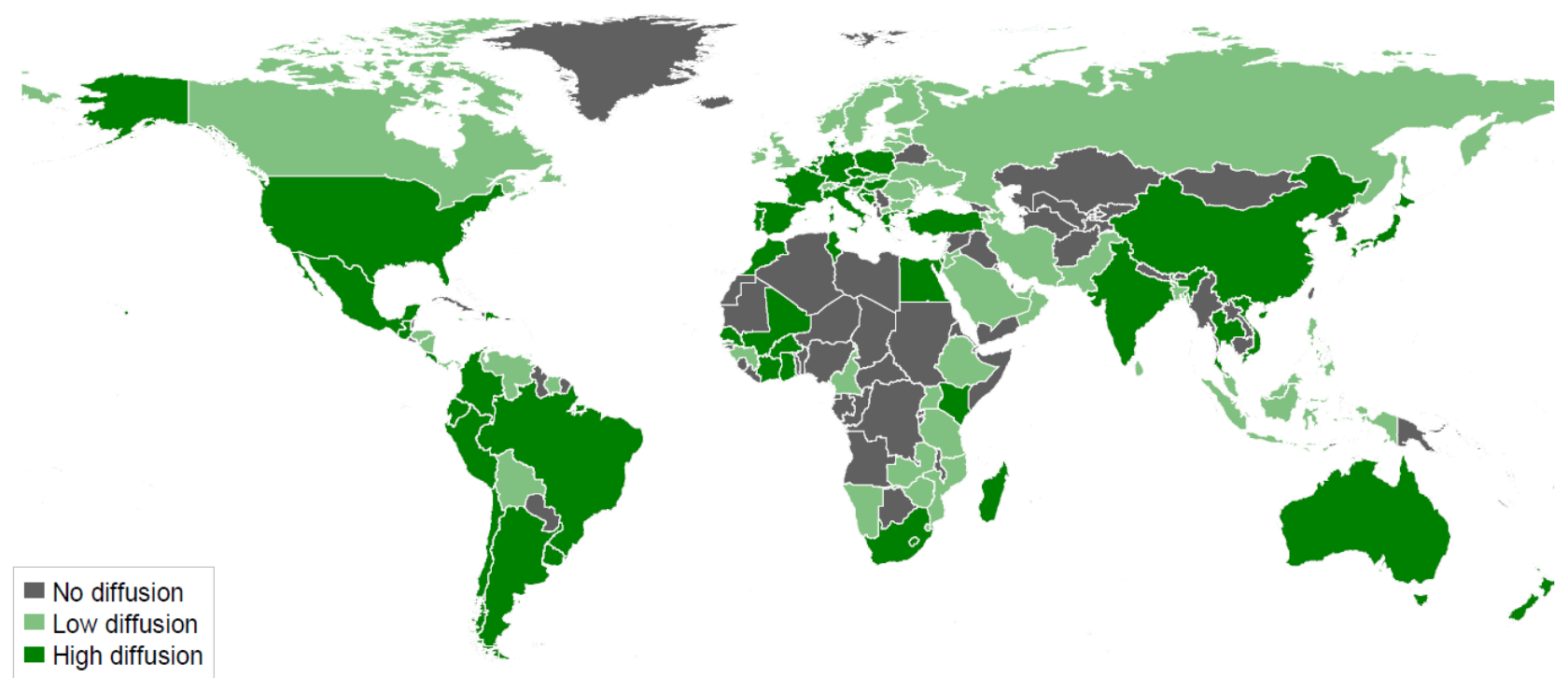

Source: Authors own depiction based on the data for year 2012

The map given above clearly shows the geographical variations of the GlobalGAP certification scheme. West Europe and some of the South American countries have the highest magnitude of certification, whereas most of Africa and parts of Asia have no certification at all. Russia, Eastern Europe as well as some of the Asian and African countries have mild penetration of the GlobalGAP standard.

\subsection{Conceptual Framework for Diffusion Process}

Awareness in the consumer markets for food safety and quality is rapidly increasing (Henson and Reardon, 2005). In order to fulfil consumer demand, retailers, especially in developed countries, are setting strict regulations to standardize procedures and product attributes. Initiated by retailers in the same context, GlobalGAP is spreading around the globe rapidly. Such certification schemes are treated in the literature as organizational innovations. Considerable work has been done to analyze the diffusion process of organizational innovations. The magnitude of certification is positively related with various macroeconomic variables (Neumayer and Perkins, 2004; Potoski and Prakash, 2004); certification is influenced by export propensity (Corbett and Kirsch, 2001); network ties such as bilateral trade and geographical proximity encourage the 
diffusion process of organizational innovation (Alburquerque et al., 2007). Furthermore, firms seek certification when their partners lack credible information (King et al., 2005). In this way, a product certified by the GlobalGAP scheme conveys a signal of quality to importer. On the other side of the supply chain, growers participate in the certification process in order to earn market access to the export market. Customer pressure and external image are two of the main driving forces to certification (Darnall and Edwards, 2006).

The intensity of GlobalGAP certification in a country can be expressed by three indicators: (a) number of GlobalGAP certificates issued; (b) number of producers accepted under the GlobalGAP certification process; (c) number of hectares harvested under GlobalGAP certification. Approval of certification is done against lists of critical control points (CCP) for all required procedures and product attributes. Such procedures could include, for example, maintenance of the sanitation facility, labeling, training the farm workers, water testing etc. Compliance with these requirements accrues some cost, both in terms of fixed costs and variable costs. On the other hand, compliance with the certification scheme brings benefits for growers in term of enhanced competency for market access to the EU. GlobalGAP is primarily required by west European markets. A representative grower aiming at enhanced competency for market access to the export market is assumed to opt for certification if they find the compliance cost for certification is exceeded by discounted benefits. In this way, by aggregating the overall number of certified producers in one country, a measure of GlobalGAP certification in that country can be calculated. Many of the conditions existing at the country level which affect the certification process are beyond the control of an individual producer. These factors affecting the diffusion process can be divided into four categories. The first category constitutes the existence of a GlobalGAP certification body and the availability of any benchmarking option. The second category includes various macroeconomic conditions prevailing in a country. The third category consists of the network ties that connect the various entities associated with food trade while the last category describes the characteristics of the agriculture sector.

In the following subsections 2.3.1 to 2.3.4, we describe these determinants of diffusion. 


\subsection{1 'Pro-GAP' Structures}

One component of the compliance cost is auditing charges (Kolk, 2000; Darnall and Edwards, 2006). In the case of certified auditor being available domestically in a country, the auditing cost would be lower, hence trimming down the total cost. In this way, the lower the cost, the higher the adoption rate will be. In this way, it can be argued that the existence of a GlobalGAP certification body in a country would increase the magnitude of participation in the standardization scheme. Barrett et al. (2002) showed that domestically available auditing facilitates encourage diffusion. In order to avoid duplication and complexity in the certification process, GlobalGAP often apply a benchmarking process to approve growers certified by other schemes that fully conform to the GlobalGAP System. The growers already participating in some local GAP scheme are already familiar with and motivated towards the certification process. In this way, the existence of such an option of benchmarking is expected to help the diffusion process.

Figure 2.2 - Conceptual Framework for the Diffusion of GlobalGAP

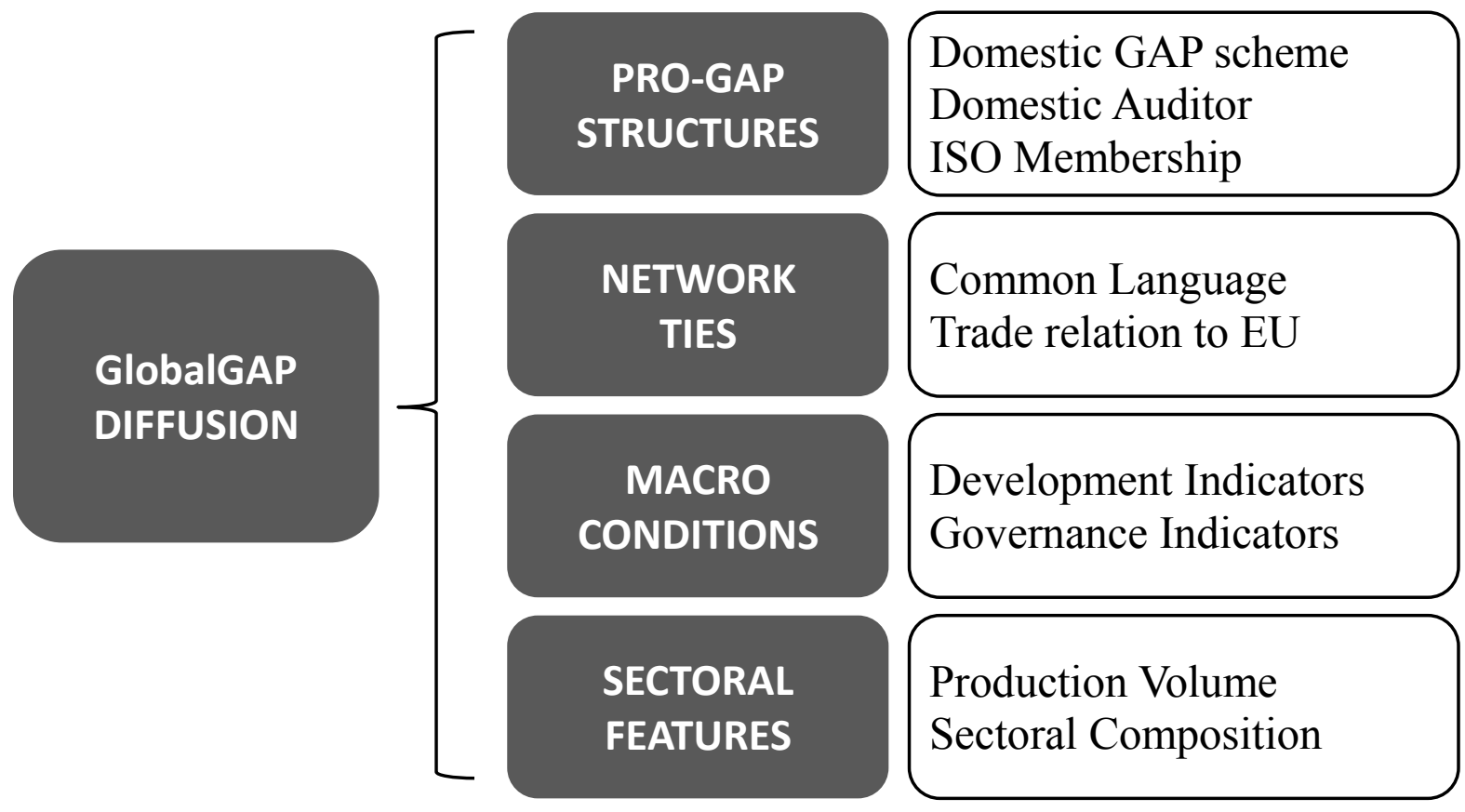

Source: Authors' own diagram based on above discussion 


\subsubsection{National Macroeconomic Conditions}

Characteristics of the national environment influence the geographic spread of organizational innovation. The level of infrastructure development is an important aspect in this regard. For instance, firms in a country with better transportation and communication systems enhance the competitiveness of the respective country's products on export markets. Consequently, growers are hypothesized to have more incentives to participate in a standardization scheme meant to fulfill a specific export market. Organizational innovations diffuse not only between nationstates, but also within them (True and Mintrom, 2001). Therefore, poor communication infrastructure makes it less likely that information will be disseminated about export requirements and potential adopters will interact with one another. In a study about diffusion of ISO certificates, Neumayer and Perkins (2005) find a positive correlation between infrastructure and intensity of certification.

Commin and Hobjin (2004) find a positive relation between real GDP and technology adoption, showing that rich economies not only invent new technologies but also have leading position in the adoption of these innovations. So diffusion of innovation can be seen much as a trickle-down effect where richer economies lead the adoption. Governance consists of the traditions and institutions by which authority in a country is exercised (Kaufman et al., 2009). Governance in a country shapes the functioning of its institutions; hence the governance level prevailing in a country affects the diffusion of organizational innovation. Herzfeld et al. (2011) find higher penetration of GlobalGAP certificates with better conditions of 'rule of law' - a governance indicator.

\subsubsection{Transnational Network Ties}

Firms are embedded in extensive relational networks that link customers, suppliers, and a host of governmental and nongovernmental organizations. These networks existing at the domestic and international level shape patterns of geo-corporate behavior (Sturgeon, 2003). Trade is one of the most important transnational networks which connects customers in one country with suppliers in another and communicates supply-chain pressures (Smith, 2003). For example, Hughes (2000) demonstrates the compliance of Kenyan floricultural suppliers to the strict requirements demanded by British retailers. Hence export competing firms have significant incentives to adopt the standards. Secondly, networks offers interaction among the different entities involved hence 
providing a way for mutual learning, for instance, about profitability of specific organizational innovations (Gertler, 2001). Considering these factors together, the arguments strongly suggest that countries that export a higher share of their agricultural output to EU markets are expected to have more GlobalGAP certification in order to compete for market access.

The patterns of diffusion across the countries are not only influenced by the contemporary linkages but also by historic factors such a colonial ties and common languages. Language commonality enhances economic activities among countries and this concept has been widely used in gravity trade models. GlobalGAP started from Europe and EU states such as Spain, Netherlands, Italy, Germany, France and Belgium are the top consumer market for GlobalGAP certified food. In this regard, language commonality with these states can be a factor of GlobalGAP diffusion in a country.

\subsubsection{Sectoral Characteristics}

A firm's specific economic sector plays a significant role in its receptivity to certain organizational practices, strategies and standards. The degree of certain innovation may vary across different economic sectors. For example, higher penetration of ISO 9000 standards in manufacturing based economies is reported by Neumayer and Perkins (2005). Similarly, Acharya and Ray (2000) showed that the industrial sector has proceeded most rapidly in acquiring certifications. Thus, the number of GlobalGAP certified enterprises in a country is expected to be affected by the magnitude of its agricultural sector and its relative share in the country's overall GDP. In this way, economies with agriculture as a minor sector are expected to show little interest in GlobalGAP certification. The number of GlobalGAP certifications can be affected by the composition of the agricultural sector and its export competency. Initially, GlobalGAP was initiated with its certification modules for fresh fruits and vegetables and over time its portfolio of standards has extended to other agricultural sectors. Herzfeld et al. (2011) support the idea that given the history of GlobalGAP certifications across the globe, countries with significant and more productive horticultural sectors in agricultural production are expected to acquire more certifications. 


\subsection{Data and Descriptive Statistics}

The study is comprised of secondary data from various sources. All data about GlobalGAP coverage is taken from the GlobalGAP Headquarters in Cologne, Germany. These data include the number of certified producers and the number of hectares certified under the standard alongside information about certification bodies as well as benchmarking data. We have a panel of five years, between 2008 and 2012. For GlobalGAP coverage in the crop subsector, the panel is only three years, from 2010 to $2012^{5}$. Data on common language is taken from CEPII. Data on cellular mobile phone subscriptions, internet subscriptions, GDP per capita and arable land per country are borrowed from World Development Indicators of the World Bank. The study borrows information on governance indicators form Kaufman et al. (2013). The data presents values of various indicators ranging from -2.5 to 2.5 . We consider Regularity Quality as a relevant governance indicator taking its 3rd quintile. FAO data on agricultural value and area harvested is included. Trade data, fruits and vegetables (HS07, HS08) imports in million USD by EU6 is taken from the ITC database. Fruit and vegetable share (\% of arable land) is the area under fruits and vegetables over the total arable land per country. This variable shows the relative size of the fruits and vegetable subsector in the agriculture sector. Agricultural value added (\% of GDP) is the share of the net value of agriculture production over the total GDP of the country. Agricultural sector openness is the share of the value of agriculture exports on the total value of agriculture production. It signifies how much a country's agricultural sector is export oriented. We hypothesize that these variables are likely to impact GlobalGAP diffusion positively. Finally, the data on ISO membership is taken from the ISO website.

In Table 2.1, we present the descriptive statistics of variables used in the analysis. The sample is divided by the country's GlobalGAP adoption status. Certified countries are those which have at least one producer adopting the GlobalGAP standard. The mean number of certified producers for all agricultural commodities is 477 . For subsector crops, the mean value for certified producers is 486 and the mean value for land coverage is around 17943.59. The number of certified producers in agriculture is slightly lower than that in the crops subsector due to the fact

\footnotetext{
${ }^{5}$ GlobalGAP data disaggregated to subsector i.e. crops, livestock, aquaculture, and individual products i.e. apple, banana, potato etc. is not available before 2010 .
} 
that the countries, where GlobalGAP exists only in livestock and aquaculture sectors, have relatively fewer certified producers, lowering the overall mean value for the agriculture sector.

Table 2.1 - Descriptive Statistics

\begin{tabular}{lccccc}
\hline \multirow{2}{*}{ Variables } & \multicolumn{2}{c}{ Non-certified } & \multicolumn{2}{c}{ Certified } & \multirow{2}{*}{ Differences } \\
& Mean & SD & Mean & SD & \\
\hline GlobalGAP producers in agriculture & & & 477.78 & 1371.73 & \\
GlobalGAP producers of crops & & & 486.95 & 1361.77 & \\
GlobalGAP hectares of crops & & & 17943.59 & 37191.1 & \\
GlobalGAP domestic auditor & & & 0.33 & 0.47 & \\
GAP benchmarked producers (\%) & & & 3.49 & 13.12 & \\
Language commonality with EU6 & 0.28 & 0.45 & 0.32 & 0.47 & 0.04 \\
Regularity quality (3 quintiles) & 1.62 & 0.78 & 2.18 & 0.72 & $1.03^{* * *}$ \\
Internet subscriptions per 100 people & 22.44 & 24.57 & 38.82 & 27.06 & $16.38^{* * *}$ \\
GDP per capita (current 1000 USD) & 9.59 & 17.54 & 13.67 & 18.04 & $4.08^{* * *}$ \\
F\&V share (\% of arable land) & 47.85 & 105.38 & 17.93 & 28.78 & $-29.92^{* * * *}$ \\
Agricultural value added (\% of GDP) & 17.66 & 15.26 & 11.01 & 9.78 & $-6.66^{* * * *}$ \\
Agricultural sector openness & 4.05 & 18.78 & 0.91 & 1.26 & $-3.14^{* * *}$ \\
F\&V imports in million USD by EU6 & 4.38 & 17.59 & 233.36 & 396.04 & $228.98^{* * *}$ \\
& & & & & \\
\hline
\end{tabular}

Table 2.1 also draws interesting differences between certified and non-certified countries with the certified countries having better governance, infrastructure and income status. This reflects that the higher the economic development of a country is, the more likely the country is to adopt the GlobalGAP standards. We also tested for the importance of the agricultural sector in these countries and found that agriculture holds much higher importance in non-certified countries. For example, the share of fruits and vegetables as a percentage of arable land, agricultural openness and agricultural value added as percentage of GDP are all much higher in non-certified countries. This might be surprising at first glance, but we argue that it shows GlobalGAP diffusion is primarily taking place in countries that are economically better placed with a relatively smaller role being played by agriculture in economic development. Hence, descriptively our data 
supports the main claim of the paper: country level characteristics are crucial for diffusion of private food standards ${ }^{6}$.

\subsection{Methodology}

The magnitude of GlobalGAP diffusion can be expressed by three indicators: (a) number of GlobalGAP certificates issued; (b) number of producers accepted under the GlobalGAP certification process; (c) hectares harvested under GlobalGAP certification. Since certification can be obtained either as an individual producer or as a group of producers, using number certification might not reflect the exact penetration of GlobalGAP as group certification does not account for the exact number of certified producers within the group. With this respect, the number of producers accepted under GlobalGAP certification is a better measure of GlobalGAP diffusion. We further argue that landholding size differs among the producers; therefore landholding by the certified producer could be the most appropriate among the three measures of diffusion. However, landholding is valid only to capture diffusion in the crop subsector, not for aquaculture and livestock. In our analysis of GlobalGAP diffusion we therefore follow a two tier approach. In the first tier we measure diffusion in the entire agriculture sector using the number of certified producers as the dependent variable. In the second tier we restrict our analysis only to the crop subsector and use the number of certified producers as well as the hectares of area harvested under GlobalGAP as the dependent variables.

We consider a five year panel for 170 FAO member states ${ }^{7}$. Since there are a number of countries that have not adopted GlobalGAP, simple OLS estimates of diffusion are likely to be biased as the impact for those who have not participated is not observed as it would be if they would have participated. We also believe that the adoption of GlobalGAP is not entirely random and our analysis contends with the issue of selection bias. To tackle such selection problems we use a Heckman two step approach. We first estimate GlobalGAP adoption as a function of the number of observables using probit estimation; calculate the inverse mills ratio (IMR) and then,

\footnotetext{
6 These differences in the observables among certified and non-certified countries are all tested for their significance and we find them all statistically different. Again, assuming non normal distribution of the dummies, we use a Willcox ranksum test for the difference. For the others we use a t-test.

${ }^{7}$ Our study involves data from various sources. There is no data at all for certain countries in one database or the other. Secondly, there are excessive missing values of key variables for some countries, hence they are dropped. Additionally, Germany and the Netherlands are dropped as no country exports to itself. Resultantly, we are left with 170 countries in the panel.
} 
in the second stage, regress the diffusion measures (non-zero) on the observables and the IMR. Thus the second stage only includes those countries who adopted GlobalGAP. Significance of IMR would imply presence of selection bias in the data. In the first stage, the selection equation should include an exclusion variable that can explain GlobalGAP adoption. The variable we use as an exclusion restriction is the ISO membership status of a country. It is a categorical variable showing four categories for ISO membership: 1 for a member body, 2 for a correspondent member, 3 for a subscriber member and 4 for a non-member. In this way, the ISO membership category of a country indicates its inclination towards standardization. Our exclusion variable shows significance at the $10 \%$ level. The ISO membership status, however, does not influence the magnitude of GlobalGAP certification, hence serves as an appropriate instrument.

Decisions on random or fixed effect models to be applied are taken on the basis of a Hausman test under the null hypothesis that the random effects model is consistent as the unobserved heterogeneity is uncorrelated with the regressors (Greene, 2012, p. 421). In case of rejection, only the fixed-effect model is considered unbiased and consistent. The fixed effects estimator, however, omits the coefficients of time invariant variables. One solution for this is to use the Mundlak approach (Mundlak, 1978) which proposes approximating the country specific effects as a function of the mean of time-variant variables.

Notably, diffusion of GlobalGAP is highly skewed (see appendix 2) across countries, whether it is taken in terms of producers or hectares. We therefore used the log of the nonzero positive values in the second stage regression. We also normalized with the total arable land of the country to capture varying country size $^{8}$.

\subsection{Regression Results}

Tables 2.2 and 2.3 report the estimation results of GlobalGAP diffusion. Table 2.2 provides the estimation of GlobalGAP diffusion in the entire agricultural sector using the log of the normalized number of certified producers as the dependent variable. Table 2.3 presents the case

\footnotetext{
${ }^{8}$ The number of GlobalGAP certified producers could be best normalized by the total number of agricultural producers in a country. However, there is no data available on this. Neumayer and Perkins (2005) normalized ISO certificates by population to make the counts comparable across different-sized countries. However, we think total arable land per country is more relevant in our case to normalize the number of GlobalGAP certified producers as it represents the size of the agricultural sector.
} 
of diffusion in the crops subsector, taking the log of the normalized number of certified producers as well as the $\log$ of the normalized hectares of area harvested under GlobalGAP as dependent variables. As discussed in the previous section, we estimate the coefficients using random effect and fixed effect settings. Among repressors we have two time invariant variables, namely common language and GlobalGAP domestic auditor. We therefore used the Mundlak approach to have an approximated fixed effect without omitting these important variables.

Table 2.2 - Estimation of GlobalGAP Diffusion in Agriculture Sector

\begin{tabular}{|c|c|c|c|}
\hline \multirow[t]{2}{*}{ Dependent variable } & \multicolumn{3}{|c|}{ Normalized no of certified producers } \\
\hline & Random effect & Fixed effect & Mundlak \\
\hline \multirow[t]{2}{*}{ GlobalGAP domestic auditor } & $1.763 * * *$ & & $1.975 * * *$ \\
\hline & $(0.183)$ & & $(0.110)$ \\
\hline \multirow[t]{2}{*}{ Language commonality with EU6 } & $1.148^{* * *}$ & & $1.141 * * *$ \\
\hline & $(0.149)$ & & $(0.143)$ \\
\hline \multirow[t]{2}{*}{ Regularity quality (3 quantiles) } & 0.275 & 0.107 & 0.039 \\
\hline & $(0.187)$ & $(0.228)$ & $(0.217)$ \\
\hline \multirow[t]{2}{*}{ Internet subscriptions per 100 people } & $0.024 * * *$ & $0.027 * * *$ & $0.024 * * *$ \\
\hline & $(0.006)$ & $(0.007)$ & $(0.007)$ \\
\hline \multirow{2}{*}{ GDP per capita (current 1000 USD) } & -0.009 & 0.008 & 0.006 \\
\hline & $(0.010)$ & $(0.016)$ & $(0.017)$ \\
\hline \multirow[t]{2}{*}{ F\&V share ( $\%$ of arable land $)$} & $0.057 * * *$ & 0.024 & $0.081 * * *$ \\
\hline & $(0.008)$ & $(0.029)$ & $(0.028)$ \\
\hline \multirow[t]{2}{*}{ Agricultural value added ( $\%$ of GDP) } & 0.015 & -0.007 & -0.009 \\
\hline & $(0.018)$ & $(0.047)$ & $(0.044)$ \\
\hline \multirow[t]{2}{*}{ Agricultural sector openness } & 0.153 & 0.169 & 0.257 \\
\hline & $(0.163)$ & $(0.190)$ & $(0.166)$ \\
\hline \multirow[t]{2}{*}{$\mathrm{F} \& \mathrm{~V}$ imports in million USD by EU6 } & $0.001 * * *$ & $0.001 * *$ & $0.001 *$ \\
\hline & $(0.000)$ & $(0.001)$ & $(0.001)$ \\
\hline \multirow[t]{2}{*}{ GAP benchmarked producers (\%) } & -0.004 & -0.005 & -0.005 \\
\hline & $(0.009)$ & $(0.009)$ & $(0.010)$ \\
\hline \multirow[t]{2}{*}{ IMR } & 0.074 & 0.099 & 0.101 \\
\hline & $(0.156)$ & $(0.182)$ & $(0.141)$ \\
\hline \multirow[t]{2}{*}{ Constant } & $-14.852 * * *$ & $-13.067 * * *$ & $-16.621 * * *$ \\
\hline & $(0.558)$ & $(0.808)$ & $(0.514)$ \\
\hline Number of Observations & 437 & 437 & 437 \\
\hline Number of countries & 102 & 102 & 102 \\
\hline Hausman test RE vs FE & \multicolumn{3}{|c|}{ Prob $>$ chi $2=0.00$} \\
\hline
\end{tabular}


Looking at Table 2.2 we find that presence of audit increases certified producers by more than $100 \%$. The positive coefficient essentially indicates that having an auditing facility in the country reduces the compliance cost of certification by reducing the transaction cost which in turn promotes the spread of GlobalGAP. This is in line with the findings from other studies, such as Hatanak et al. (2005) and Barret et al. (2002). Language appears to have a positive and significant coefficient implying that cultural closeness and historical relations between the EU and its importer countries promotes business activities and diffusion of GlobalGAP.

This result remains the same in the random effect and the Mundlak estimation. Since audit and language variables are time invariant in nature, they are dropped in the fixed effects model. For the other variables we additionally compare the fixed effects model and observe the positive and significant impacts of the share of fruit and vegetable production and their exports to the EU. GlobalGAP originally started with fruits and vegetables and the significance of these variables indicates the importance of the fruit and vegetable sector in GlobalGAP diffusion. Furthermore, we tested for the importance of the infrastructure conditions. In this respect, we find that internet coverage exerts a significantly positive impact indicating that access to the internet improves worldwide connectivity and the spread of information which then promotes diffusion. However, its significance vanishes in the fixed effects model. Other variables, such as governance indexes, agricultural openness, per capita GDP, share of agriculture in GDP and benchmarking mostly remain insignificant in all the panel models.

In Table 2.3 we restrict our analysis only to the crop subsector and use the number of certified producers and area harvested under the GlobalGAP scheme as measures of diffusion. The results remain more or less similar to those in Table 2, except that fruit and vegetable imports appear with significant coefficients in the random effect model where diffusion is measured as area harvested under the certification scheme. With hectares of and harvested under certification, we additionally find that in the random effects model the governance index and the country's income have positively significant impacts on GlobalGAP diffusion. This shows that better governance and higher income of the countries promotes economic stability influencing the spread of certification. 
Table 2.3 - Estimation of GlobalGAP Diffusion in Crops Subsector

\begin{tabular}{|c|c|c|c|c|c|c|}
\hline Dependent variable & Norm: & zed no of & rtified & Norma & d hectar & s of land \\
\hline & Random & Fixed & Mundlak & Random & Fixed & Mundlak \\
\hline GlobalGAP domestic auditor & $\begin{array}{c}2.056 * * * \\
(0.259)\end{array}$ & & $\begin{array}{c}1.921 * * * \\
(0.165)\end{array}$ & $\begin{array}{c}3.566^{* * * *} \\
(0.257)\end{array}$ & & $\begin{array}{c}3.474 * * * \\
(0.189)\end{array}$ \\
\hline Language commonality with EU6 & $\begin{array}{c}1.187 * * * \\
(0.168)\end{array}$ & & $\begin{array}{c}1.432 * * * \\
(0.159)\end{array}$ & $\begin{array}{c}1.917 * * * \\
(0.268)\end{array}$ & & $\begin{array}{c}2.258^{* * *} \\
(0.246)\end{array}$ \\
\hline Regularity quality (3 quantiles) & $\begin{array}{c}0.441 \\
(0.300)\end{array}$ & $\begin{array}{c}0.087 \\
(0.307)\end{array}$ & $\begin{array}{c}0.063 \\
(0.329)\end{array}$ & $\begin{array}{l}0.728^{*} \\
(0.394)\end{array}$ & $\begin{array}{c}-0.004 \\
(0.246)\end{array}$ & $\begin{array}{l}-0.116 \\
(0.327)\end{array}$ \\
\hline Internet subscriptions per 100 people & $\begin{array}{c}0.011 \\
(0.009)\end{array}$ & $\begin{array}{c}0.004 \\
(0.012)\end{array}$ & $\begin{array}{c}0.002 \\
(0.012)\end{array}$ & $\begin{array}{c}0.019 \\
(0.022)\end{array}$ & $\begin{array}{c}0.005 \\
(0.029)\end{array}$ & $\begin{array}{l}-0.001 \\
(0.032)\end{array}$ \\
\hline GDP per capita (current 1000 USD) & $\begin{array}{l}-0.022 \\
(0.019)\end{array}$ & $\begin{array}{c}-0.031 \\
(0.038)\end{array}$ & $\begin{array}{l}-0.035 \\
(0.035)\end{array}$ & $\begin{array}{c}-0.039 * * \\
(0.020)\end{array}$ & $\begin{array}{c}-0.028 \\
(0.043)\end{array}$ & $\begin{array}{l}-0.037 \\
(0.041)\end{array}$ \\
\hline $\mathrm{F} \& \mathrm{~V}$ share (\% of arable land) & $\begin{array}{c}0.064 * * * \\
(0.007)\end{array}$ & $\begin{array}{l}0.101 * \\
(0.052)\end{array}$ & $\begin{array}{c}0.126^{* * * *} \\
(0.033)\end{array}$ & $\begin{array}{c}0.059 * * * \\
(0.009)\end{array}$ & $\begin{array}{c}0.073 \\
(0.145)\end{array}$ & $\begin{array}{c}0.126 * * \\
(0.060)\end{array}$ \\
\hline Agricultural value added (\% of GDP) & $\begin{array}{c}0.010 \\
(0.019)\end{array}$ & $\begin{array}{c}0.028 \\
(0.043)\end{array}$ & $\begin{array}{c}0.027 \\
(0.037)\end{array}$ & $\begin{array}{l}-0.013 \\
(0.033)\end{array}$ & $\begin{array}{l}-0.025 \\
(0.082)\end{array}$ & $\begin{array}{l}-0.043 \\
(0.067)\end{array}$ \\
\hline Agricultural sector openness & $\begin{array}{c}0.125 \\
(0.179)\end{array}$ & $\begin{array}{c}0.246 \\
(0.331)\end{array}$ & $\begin{array}{c}0.290 \\
(0.338)\end{array}$ & $\begin{array}{c}0.042 \\
(0.242)\end{array}$ & $\begin{array}{c}0.194 \\
(0.494)\end{array}$ & $\begin{array}{c}0.288 \\
(0.517)\end{array}$ \\
\hline F\&V imports in million USD by EU6 & $\begin{array}{c}0.001 * * * \\
(0.000)\end{array}$ & $\begin{array}{l}0.002 * * \\
(0.001)\end{array}$ & $\begin{array}{c}0.002 * * \\
(0.001)\end{array}$ & $\begin{array}{c}0.002 * * * \\
(0.000)\end{array}$ & $\begin{array}{c}0.002 \\
(0.001)\end{array}$ & $\begin{array}{c}0.001 \\
(0.001)\end{array}$ \\
\hline GAP benchmarked producers $(\%)$ & $\begin{array}{c}0.001 \\
(0.010)\end{array}$ & $\begin{array}{c}0.001 \\
(0.019)\end{array}$ & $\begin{array}{l}-0.000 \\
(0.018)\end{array}$ & $\begin{array}{c}0.001 \\
(0.009)\end{array}$ & $\begin{array}{c}0.005 \\
(0.014)\end{array}$ & $\begin{array}{c}0.002 \\
(0.013)\end{array}$ \\
\hline IMR & $\begin{array}{c}0.029 \\
(0.100)\end{array}$ & $\begin{array}{c}0.044 \\
(0.155)\end{array}$ & $\begin{array}{c}0.052 \\
(0.102)\end{array}$ & $\begin{array}{l}-0.047 \\
(0.120)\end{array}$ & $\begin{array}{l}-0.015 \\
(0.176)\end{array}$ & $\begin{array}{l}-0.059 \\
(0.118)\end{array}$ \\
\hline Constant & $\begin{array}{c}-14.60 * * * \\
(0.820)\end{array}$ & $\begin{array}{c}-13.26 * * * \\
(1.382)\end{array}$ & $\begin{array}{c}-17.45^{* * *} * \\
(0.500)\end{array}$ & $\begin{array}{c}-13.51 * * * * \\
(1.289)\end{array}$ & $\begin{array}{c}-9.70 * * * \\
(3.234)\end{array}$ & $\begin{array}{c}-17.50 * * * \\
(0.711)\end{array}$ \\
\hline Number of Observations & 274 & 274 & 274 & 274 & 274 & 274 \\
\hline Number of countries & 100 & 100 & 100 & 100 & 100 & 100 \\
\hline
\end{tabular}

Note: Dependent variables are in log form. Robust Standard errors are reported in the parentheses after bootstrapping with 500 replications; *** $\mathrm{p}<0.01, * * \mathrm{p}<0.05, * \mathrm{p}<0.1$; number of observation falls slightly due to missing values in data; dependent variable is normalized by size of total arable land 


\subsection{Conclusion}

Using a five year panel for 170 countries, our study analyzes the diffusion of GlobalGAP certification at the country level. We argue that other than firm level factors which have been studied extensively by a large number of studies, macro factors also contribute to the spread of private food standards, such as GlobalGAP. However, studies on this front are still relatively scarce.

We measure diffusion at the crop level and for the entire agricultural sector using the number of producers accepted under GlobalGAP certification and the hectares harvested under GlobalGAP in crops. These variables are all normalized by size of arable land in the country. In the estimation of the diffusion model, we face the problem of selection bias as the impact of GlobalGAP for those countries who have not adopted it remains unobserved. To tackle this, we use a Heckman two part; in the first stage we estimate adoption of GlobalGAP using ISO membership by countries as an instrument. For the second stage, we plug in the IMR estimated from the first stage to control for the selection bias. The second stage uses only the truncated sample.

So far the spread of the standardization scheme has been highly skewed around the globe. We therefore hypothesize that numerous factors such as geographic preconditions, network ties and historical relations of countries as well as various indicators for economic development and the governance level prevailing in a country influence spread of GlobalGAP.

In our estimation, we find that the domestic availability of auditing facilities encourages certification. This might be caused by the lowering of compliance costs due to locally available auditing systems. Analyzing the role of transnational network ties in certification, it is found that countries connected through common languages with EU states are likely to adopt GlobalGAP. Common language facilitates mutual business activities among these states. In the same way, countries with high exports of fruits and vegetables to EU states have higher diffusion. An implication of such network ties is that they reinforce retailer-supplier relations within networks. Consequently, it makes the inclusion of new entrants harder. We find a positive impact of the fruits and vegetables sector on certification magnitude. Since GlobalGAP originally started with 
this sector, it holds great importance in the spread of GlobalGAP. Our estimates show a higher share of fruits and vegetables as a percentage of arable land.

Clearly, this study only focuses on the country level diffusion process. To include farm level characteristics of each country is obviously beyond the scope of this work. There are certain mechanisms available to the growers for financial aid and other support which can facilitate adoption in certain countries. Due to a lack of data, we could not consider this aspect in our estimation. This represents a limitation of the current study. Further investigations are therefore needed to analyze the diffusion process of certification schemes in the agrifood sector. 


\title{
3 Impact of GlobalGAP Certification on EU Banana Imports: A Gravity Modeling Approach
}

\author{
Amjad Masood, Bernhard Brümmer \\ Department of Agricultural Economics and Rural Development, \\ University of Göttingen, Germany \\ Sören Prehn \\ Leibniz Institute of Agricultural Development in Central and Eastern Europe, Germany
}

\begin{abstract}
Adopting a gravity framework and using data from 2010 to 2012 for 74 countries, we investigate whether the intensity of GlobalGAP standard adoption has a positive impact on EU banana import values. Intensity is measured by using the number of GlobalGAP certified producers and hectares harvested under GlobalGAP certification. Using random and fixed effect estimation, we find that the intensity of certification, in terms of producers and hectares is associated with higher banana imports. However the estimated elasticities of imports in all models are less than 1, indicating an inelastic response of imports to GlobalGAP certification intensity. This also indicates that the small farmers in developing countries who find it difficult to comply with the GlobalGAP standard requirements are driven out of the international banana market. For the gravity variables, distance is found to have a negative impact, but banana production in the exporting countries and the presence of a common language and RTA between the trading countries improves trade.
\end{abstract}

Keywords: Banana imports of EU; Private food standard; GlobalGAP; Gravity model 


\subsection{Introduction}

Food trade between agriculture based economies and the developed economies constitutes a significant portion of global trade. The recent evolutions in regulatory practices due to new standards and certification schemes is one of the major factors affecting the pace and pattern of global trade. Private standards are playing an increasing role in the governance of agricultural and food supply chains (Henson, 2006). Private standards have become much more important in global agri-food value chains over last two decades, and these standards can be seen as filling a void in international rules. For example, in countries where national regulatory standards are scarce, private standards are seen to define standard requirements in primary production (Henson and Humphrey, 2009). In fact, private standards set a higher standard for particular food product attributes, and provide additional requirements for the end-product than the requirements laid down by public regulations. The contents of private regulations are readily reviewed in order to incorporate consumers' varying preferences, for the sake of product differentiation and price premiums. Hence, in spite of the pre-existence of public regulations, private standards emerged rapidly during the last few decades.

Even though standard adoption has become an integral part of international food trade, especially for developed countries mainly due to quality concerns, according to the literature, standards can have positive and negative effects. For example, one of the most studied issues concerning standards is their impact on international trade volume. In the literature the evidence on this is rather mixed. While one body of literature suggests that standards could lead to export gains by modernizing the food supply chains through innovation and upgrading (Swinnen, 2007), the other highlights how standards constitute impediments to countries' exports, especially through their high compliance costs, thereby acting as non-tariff barriers to trade (Olper and Raimondi, 2008; Li and Beghin, 2012; Blind and Jungmittag, 2005; Swann, 2010). Furthermore, few studies have also discussed the impact of standards on international competitiveness of domestic farmers. Since standards serve as quality signals in international food trade, they can stimulate product competitiveness (Maertens and Swinnen, 2009; Henson et al., 2011). On the other hand, standards can also have anti-competitive effects in international trade as those who are unable to meet the high cost of standards compliance are often driven out of the international market. Finally, standards can help to overcome the 'lemons' problem in international trade, by reducing 
the degree of asymmetric information on the quality of products (Leland, 1979).

The review of literature above suggests that standards could either be catalysts or impediments to international trade. In general, our study aims to reveal the impact of private standards on trade flows and. In particular, this study examines the impact of GlobalGAP in the agrifood sector. We contribute to the existing debate on "standards are barriers or catalysts?" in several ways. First, the trade effect of private food standards has been largely studied empirically within the framework of gravity models. However, so far, little attention has been paid to the relationship between the intensity of private standards and the trade volume. This could be important, however, because the enhancement of traded products occurs not only from standard adoption but also from intensity of certification. Second, so far, on the impact of standards on trade volume, the literature has mostly catered for public food safety and quality standards and very little has been done in the area of private standards. Our study takes the case of private standards and examines the impact of GlobalGAP certification intensity on banana imports of the European Union. To this end, we use disaggregated data on banana import from 74 countries to the European Union (EU) using a gravity modeling framework. Finally, there are few studies that have analyzed the welfare effects of GlobalGAP certification. For example, Asfaw et al. (2009) and Kersting and Wollni (2012) analyzed GlobalGAP adoption by small-scale farmers in Kenya and Thailand respectively. These studies mainly focus on firm level data and identified factors such as household characteristics, cost of compliance, private-public partnership and support from donors (Kertsting and Wollni, 2012) as crucial determinants of standard adoption.

In the area of impact analysis of policy regulation on trade, there is a large body of literature available. However, most of the studies focused on regulations such as SPS, TBT, and HACCP standards while some others consider the ISO standards (e.g. Otsuki et al., 2001; Wilson and Otsuki, 2004; Anders and Caswell, 2009; Xiong and Beghin, 2011; Ferro et al., 2013). So far there is not a single study on the impact of GlobalGAP on international trade. We look at this case by analyzing GlobalGAP certified banana imports of the EU. Our study considers a three year panel from 2010 to 2012 for 74 banana exporting countries.

The main finding of the paper suggests that GlobalGAP intensity, measured by the number certified producers and the number of hectares harvested under banana certification, has a positive impact on imports i.e. an increase in intensity leads to increased banana imports. 
Therefore GlobalGAP acts as a catalyst. However, this response of import to certification is inelastic in nature. It might reflect the fact that GlobalGAP probably has a crowding out impact on the non-certified producers.

The rest of the paper is organized in the following manner. Section 3.2 provides an overview of GlobalGAP certification in general agricultural commodities including banana. In Section 3.3 we develop a conceptual framework of our analysis. Sections 3.4 and 3.5 describe the methodology and data respectively. Section 3.6 explains the results of the gravity model and finally Section 3.7 concludes the study.

\subsection{Overview of GlobalGAP Certification in Banana}

GlobalGAP is a pre-farm-gate business to business voluntary standard. It has established itself as a key reference for Good Agricultural Practice (GAP) that concerns aspects of food safety, environmental protection, workers' health, safety and welfare, and traceability (FoodPLUS and GTZ, 2008) in the global market place. The GlobalGAP standard outlines requirements for ' good agricultural practices' in the phase of primary production where international standards are scarce (Henson and Humphrey, 2009). In countries including Austria, Chile, Denmark, France, Germany, Japan, Kenya, Mexico, New Zealand, Spain, and the UK, GlobalGAP has been incorporated into domestic GAP standards, usually in the form of public-private joint ventures (Mitchell, 2008). The standard was initially known as EUREPGAP when it started back in 1997 by retailers associated with the Euro-Retailer Produce Working Group (EUREP). It was subsequently renamed GlobalGAP in 2007 as more and more producers and retailers around the globe got connected over time.

According to the GlobalGAP Annual Report in 2012, the standards possess a network of 1400 trained inspectors and auditors working for 142 accredited certification bodies and certifying 409 agricultural products in 112 countries. However, the worldwide spread of GlobalGAP is quite uneven. Some countries, such as Chile, Italy, Kenya, Peru and South Africa all have relatively high coverage of GlobalGAP. On the other hand, several countries (e.g. Jamaica, Venezuela, and Indonesia) only possess one or a few certifications. Among continents, Europe accounts for the largest portion of GlobalGAP coverage at 74 percent. The percentage shares of Asia, Africa, the Americas and Oceania are 8 percent, 5 percent, 12 percent and 1 percent respectively 
(GlobalGAP, 2012). Because of its extensive coverage, GlobalGAP is an appropriate scheme to analyze the impact of private food standards on international trade flows.

The certification of the standard also varies among different agriculture sectors. GlobalGAP covers 8 percent of livestock suppliers, 22 percent of aquaculture and the majority of GlobalGAP suppliers are crop growers with a share of 20 percent. Within the crops subsector, the most important area is vegetables and fruits, having a 78\% share (GlobalGAP, 2012).

There are a total of 29 countries where GlobalGAP certification for bananas exists. These countries are Brazil, Chile, Côte d'Ivoire, Cameroon, Colombia, Costa Rica, Dominican Republic, Ecuador, Egypt, Spain, Ethiopia, France, Ghana, Guatemala, Honduras, India, Kenya, Lebanon, Saint Lucia, Morocco, Mexico, Mozambique, Panama, Peru, Philippines, Suriname, Swaziland, Thailand and South Africa. Figure 3.1 shows the GlobalGAP coverage of banana cultivation in various countries. The green shade represents countries who cultivate at least some of their bananas under the GlobalGAP certification scheme. Other countries which cultivate banana without GlobalGAP certification are shown in a yellow shade. Grey shade on the map indicates no banana production? ${ }^{9}$.

Figure 3.1 - GlobalGAP Certification of Bananas around the World

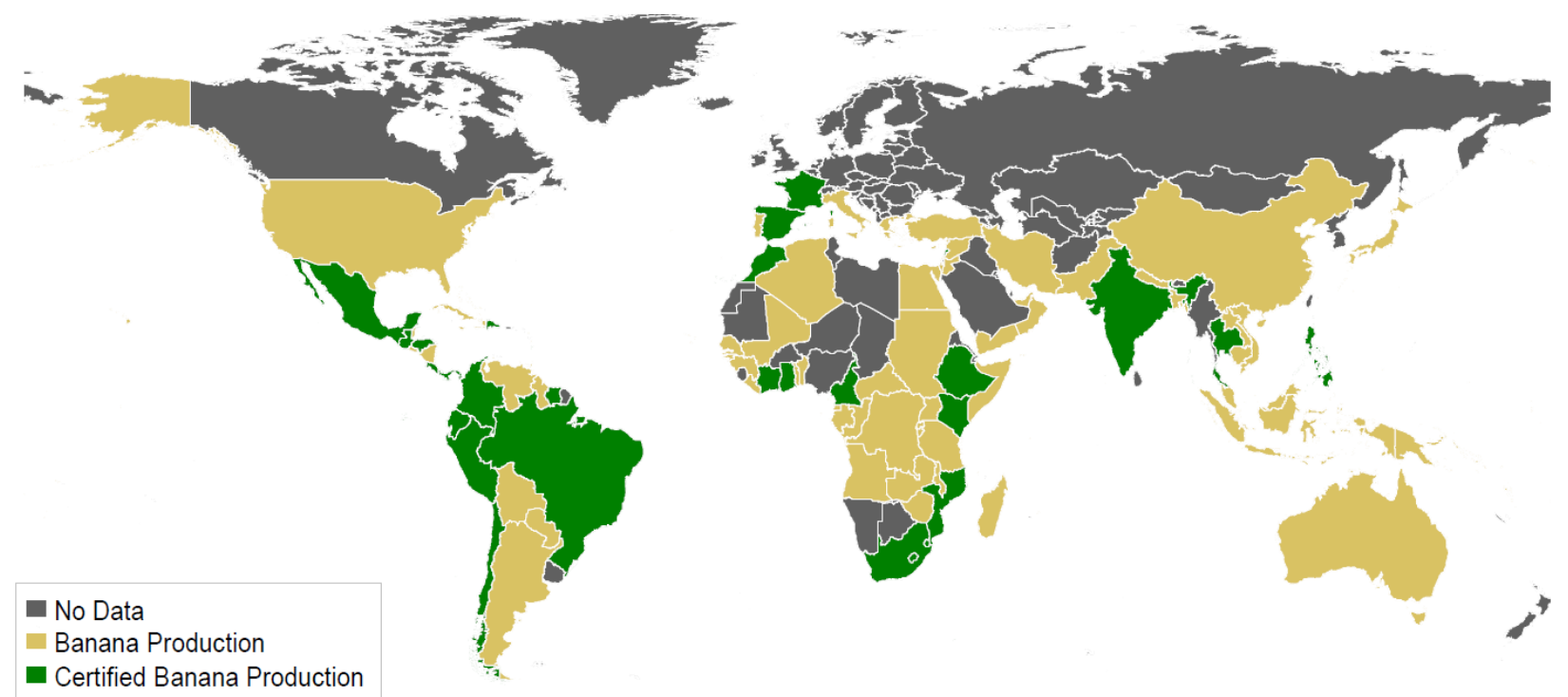

Source: Authors own depiction based on the data for year 2012

\footnotetext{
${ }^{9}$ The map is based on banana production data reported by FAO. "No Data" mean no production reported.
} 
Among GlobalGAP products, bananas have the highest magnitude of coverage with 243,400 hectares of certified cultivation (GlobalGAP, 2011). Of all the fruits, bananas have the highest volume of production among all fruits, and are among the five most consumed fruits (FAO, 2011). This clearly makes bananas an important product in the vegetables and fruit sector. Therefore, not only are bananas highly significant as food items, they are the best commodity to represent the GlobalGAP certification coverage in the fruits and vegetables sector. Furthermore, the banana is a tropical fruit. There is nearly no banana production within the European Union ${ }^{10}$ Therefore, most of bananas are imported from tropical and subtropical countries into the EU. Most bananas are traded as fresh fruit. There are plantains and banana chips as well but they are traded in marginal quantities. This adds a computational advantage. We therefore focus on the trade in fresh bananas in our analysis.

\subsection{Conceptual Framework}

In the current scenario, the prevailing standards are huge in number and diverse in nature, and they are implemented along the supply chain right from the production of any commodity to its ultimate consumption. These standards can behave like trade facilitators, or they may be trade restrictors (Reardon et al., 2009; Maertens and Swinnen, 2009). Based on the existing literature in this section we develop a conceptual framework on the probable impacts of standards on international trade.

There have been a number of studies that have discussed the impact of standards on trade and the evidence concerning the probable direction of this impact seems ambiguous.

From the supply side, on one hand standards could facilitate international trade by improving access to new markets, increasing price premiums, enhancing product quality, product differentiation and increasing cooperation between producers and agribusinesses (Giovannucci and Ponte, 2005; Asfaw et al., 2007; Kersting and Wollni, 2012). On the other hand, adoption of a standard usually requires substantial investment in technological and infrastructural changes.

\footnotetext{
${ }^{10}$ A small quantity of bananas are grown in some tropical and subtropical territories of EU states which include the Canary Islands, the French overseas departments of Guadeloupe and Martinique, Madeira and the Azores, whereas bananas produced in Cyprus, Greece and continental Portugal constitute almost $1 \%$ of the total EU. This banana production within the EU accounts for about 12\% of total EU consumption in 2012 (EU commission, 2013)
} 
Compliance to certain standards may raise fixed costs, variable costs or both ${ }^{11}$. The presence of fixed costs suggests the presence of scale economies and imperfect competition. It also requires a dynamic perspective, for instance, the fixed costs for adopting standards will occur only once. Resource-poor farmers might not be able to finance these investments if they do not have access to credit or other sources of liquidity. Moreover, farmers in developing countries often do not have sufficient access to market information and extension services which could be useful to help comply with standards (Boselie and van de Kop, 2005; Narrod et al., 2009; Vorley and Fox, 2004). Therefore, due to financial constraints, lack of technical knowledge and market information standards might drive small farmers out of export market. Furthermore, for exporters, increased costs of monitoring and providing technical support due to standard adoption might act as a barrier to entry into the international market (GTZ, 2010; Ouma, 2007; MacGregor and Graffham, 2009). Finally, on the other end of the market chain, the certified products may earn a higher consumer satisfaction because of better matching consumer preferences but may discourage demand due to the higher price. Thus private food safety standards might act as barriers to entry for small farmers and exporters, effectively precluding access to potentially lucrative export markets (World Bank, 2005).

In case of GlobalGAP, several authors conclude that certification has positive effects for producers and provides developing countries with potentially valuable opportunities in the global agrifood market. GlobalGAP promotes access to high-value export markets and improves farming knowledge thus increasing the price received by farmers (Graffham and MacGregor, 2007; Graffham et al., 2007; Henson et al., 2011). Jaffee and Henson (2004) show how Peru exerted efforts to upgrade food safety capacity in line with GlobalGAP and resultantly could position itself as a globally competitive exporter of fresh and processed asparagus. In another case, UNCTAD (2007) presents the example of Thailand, Malaysia and Vietnam, which have been historically less reliant on EU markets than some of their international competitors, but could easily enable themselves to comply with private standards such as GlobalGAP.

\footnotetext{
${ }^{11}$ Fixed costs are the initial investment costs incurred only once, such as the costs for physical upgrading, initial training and the development and establishment of new procedures and management systems. Variable costs, in contrast, are the costs that have to be incurred on a regular basis, such as the additional costs for laboratory analyses, management and annual certification costs (Kersting and Wollni, 2012). While fixed costs are the main barriers to initial adoption of standards, variable costs affect the sustainability of standard compliance (Chemnitz et al., 2007; Jaffee et al., 2005).
} 
There is a certain cost of compliance for GlobalGAP in addition to the requirement for certain activities in order to attain certified banana cultivation. With these extra efforts on the part of growers, there are benefits in term of product differentiation. The certification serves as a mechanism to convey a quality signal to the consumers. The European Union constitutes the main demand for GlobalGAP certified products. For this reason, we expect a net positive impact of the GlobalGAP standard on the considered trade flow i.e. EU imports.

In Table 3.1 we summarize the discussion mentioned above and the potential effects of standards are decomposed into 'effect components' in order to analyze possible impact on trade flow. Notably, these 'components' are not considered in this study to be modeled directly as the traditional gravity variable, rather they are considered to reveal an analytical analogy in terms of their role in trade flows as these components ultimately contribute towards the 'enhanced demand effect' and 'trade cost effect', hence modifying the net trade flows.

Table 3.1 - Potential Impacts of a Standard on Trade Flow

\begin{tabular}{lll}
\hline Standard's effect & Trade flow & Theoretical reasoning \\
\hline Harmonization & + & Mutual recognition smoothens trade and reduces transaction cost \\
Safety \& Quality & + & Signals for consumer evaluation for enhanced quality \\
Product differentiation & + & $\begin{array}{l}\text { Broadens consumer market and enables firms to claim product } \\
\text { superiority } \\
\text { Cost Effect }\end{array}$ \\
& - & $\begin{array}{l}\text { Enhanced fixed cost for upgrading equipment and practice codes } \\
\text { as well as variable costs such as the cost of inspection procedures } \\
\text { at custom points }\end{array}$ \\
Delaying Effect & - & $\begin{array}{l}\text { Analogous to fixed and variable costs but in terms of time } \\
\text { Drive out effect }\end{array}$ \\
\hline
\end{tabular}

\subsection{Methodology}

Over the course of time, the gravity trade model has been developing both in terms of addition of new explanatory variables as well as econometric techniques of estimation. The traditional gravity equation has been applied in log-linearized form until Santos Silva and Tenreyo (2006) put forward a seminal work arguing that the gravity model should rather be used in multiplicative 
form, rather than being estimated in logarithmic form. Under heteroskedasticity, the parameters of log-linearized models estimated by OLS lead to biased estimates of the true elasticities. French (2011) implicates that the gravity trade model analysis should be estimated at the product level and then should be re-aggregated. He analytically demonstrates that the gravity trade model estimated over the product level does not converge, on aggregation, to the standard aggregate Anderson and van Wincoop (2003) gravity trade model. The underlying reason is that the outward multilateral resistance term of the AvW Model should be non-constant, varying by importer. French's work underlines the importance of deeper statistical analysis. In addition to the $\log$ transformation, treatment of excessive zero trade and over dispersion are two other complications in gravity estimations. Zero trade occurs because of no actual trade between two countries or the magnitude of trade has been rounded to zero, while overdispersion occurs whenever conditional variance is larger than the value expected by the given statistical model.

In order to deal with the problem of excess zeros, there are two types of statistical approaches: zero-inflated Count Data models and Two-Part models. Rose (2004) uses the Tobit model in order to treat zero trade flows. Santos Silva and Tenreyo (2006) use the Poisson Pseudo Maximum Likelihood (PPML) estimator for dealing with zero trade flows, yet Martinez-Zarzoso et al. (2007) find that PPML is not always the best estimator as it is outperformed by other estimators such as OLS.

In order to incorporate the multilateral resistance terms for exporter and importer, we applied a remoteness approach. According to Head (2003), remoteness measures a country's weighted distance from its trading partners where the share of world GDP of the partner countries are taken as the weights. However, Baier and Bergstarand (2009) advanced this concept using a Taylor series approximation to linearized estimation of the multilateral residence terms. This linearization implies that bilateral trade between the country pair depends upon the bilateral trade cost in proportion to the multilateral trade cost and the multilateral trade cost relative to the world trade cost.

Decisions on whether random or fixed effects models to be applied are taken on the basis of a Hausman test under the null hypothesis that the random effects model is consistent as the unobserved heterogeneity is uncorrelated with the regressors (Greene, 2012, p. 421). In the case of rejection, only the fixed-effects model is considered unbiased and consistent. The fixed effects 
estimator, however, omits the coefficients of time invariant variables. One solution for this is to use the Mundlak approach (Mundlak, 1978) which proposes approximating the country specific effects as a function of the mean of time-variant variables.

Considering the above mentioned discussion, we specify our gravity trade equation as given below.

$\operatorname{lnbnimp}_{\mathrm{ijt}}=\beta_{0}+\beta_{1} \operatorname{lnbngp}_{\mathrm{it}}+\beta_{2} \operatorname{lnbnprv}_{\mathrm{it}}+\beta_{3} \operatorname{lnbncon}_{\mathrm{jt}}+\beta_{4} \operatorname{lndist}_{\mathrm{ij}}+\beta_{5} \ln (1+$ $\left.\operatorname{tariff}_{\mathrm{ijt}}\right)+\beta_{6} \operatorname{col}_{\mathrm{ij}}+\beta_{7} \mathrm{rta}_{\mathrm{ijt}}+\beta_{8} \operatorname{lang}_{\mathrm{ij}}+\delta_{\mathrm{i}}+\varphi_{\mathrm{j}}+\gamma_{\mathrm{t}}+\varepsilon_{\mathrm{ijt}}$

Here, bnimp $_{\mathrm{ijt}}$ is the banana imports from exporter $\mathrm{i}$ to importer $\mathrm{j}$ at time $\mathrm{t}$; bngp $_{\mathrm{it}}$ is number of banana producers under the GlobalGAP certification process for exporter i at time $\mathrm{t}$; bnprv $_{\mathrm{it}}$ is the banana output for exporter $\mathrm{j}$ at time $\mathrm{t}$; bncon $_{\mathrm{jt}}$ is banana consumption for importer $\mathrm{j}$ at time $\mathrm{t}$; $\operatorname{tariff}_{\mathrm{ijt}}$ is ad valorem import tariff applied by importer $\mathrm{j}$ on exporter $\mathrm{i}$ at time $\mathrm{t}$; dist $\mathrm{ij}_{\mathrm{j}}, \operatorname{col}_{\mathrm{ij}}, \mathrm{rta}_{\mathrm{ijt}}$, and $\operatorname{lang}_{\mathrm{ij}}$ are common gravity variables for distance, colonial ties, regional trade agreement and common language respectively; $\delta_{\mathrm{i}}, \varphi_{\mathrm{j}}$ and $\gamma_{\mathrm{t}}$ are fixed effects; $\varepsilon_{\mathrm{ijt}}$ is the error term; and $\beta$ s are the coefficients to be estimated.

\subsection{Data and Descriptive Statistics}

Secondary data is used for the estimations in this study. We have a panel of three years 2010, 2011 and 2012 with 74 banana countries which produces as well as exports bananas alongside 27 EU states as importers ${ }^{12}$. For the magnitude of GlobalGAP certification, we have data in two forms: the number of banana producers per country accepted under the certification process and the total area harvested per country under GlobalGAP certified banana cultivation ${ }^{13}$. Data on banana imports for the EU27 is sourced from the International Trade Center (ITC) Trade Map database. This data is taken at HS4 level i.e. HS-0803 which is bananas and plantains, fresh or

\footnotetext{
${ }^{12}$ As we are primarily interested in the impact of GlobalGAP and pre-farm gate standards, a country which does not produce bananas but only re-exports is not included as an exporter in our estimation.

${ }^{13}$ GlobalGAP data in terms of producers is available for all 29 countries listed above. However, data availability in terms of number of hectares of certified bananas is restricted, due to GlobalGAP data privacy policy, to only 14 countries including Côte d'Ivoire, Colombia, Costa Rica, Dominican Republic, Ecuador, Spain, France, Guatemala, Honduras, India, Saint Lucia, Panama, Peru and South Africa.
} 
dried. Ideally there must be segregation between banana and plantains. Unfortunately the database only became differentiated to higher HS levels after 2012. However, major trade only occurs in banana, not in plantains ${ }^{14}$. Hence we find estimation at the HS-0803 level is still appropriate in our case. Banana production data in a country is taken from the FAO. Traditional gravity variables including distance, colonial relationship, common language between country pair is sourced from CEPII. We also include WTO data on regional trade agreements between trading partners. We consider ad valorem equivalent tariffs on banana imports by the EU27. Data on tariffs is taken from the ITC Market Access Map (MAcMap) database.

Table 3.2 shows mean, standard deviation, mimumum and maximum value of different variables used in the study. As our sample includes countries with no certification as well, we have zero values for GlobalGAP variables, the first two variables here in the list under the minimum value column. Zero import is a common trade fact. The maximum import value is marked by banana import of Belgium from Colombia in 2011. Gross banana production value is taken at 1000 USD. The minimum banana production value in the sample is 20 thousand USD for Rwanda. The last three are dummy variables. We can see that colonial relationships exist for 4 percent of country pairs whereas the presence of common language is slightly higher, i.e. 7 percent.

Table 3.2 - Descriptive Statistics

\begin{tabular}{lrrrr}
\hline Variable & Mean & SD & Min & Max \\
\hline & & & & \\
GlobalGAP certified producers & 48.75 & 183.73 & 0 & 978 \\
GlobalGAP certified hectares & 2266.25 & 8777.02 & 0 & 70982 \\
Banana imports (1000 USD) & 245.04 & 2215.12 & 0 & 65863.1 \\
Banana production (1000 USD) & $4.63 \mathrm{E}+05$ & $1.33 \mathrm{E}+06$ & 20 & $1.10 \mathrm{E}+07$ \\
Banana consumption (1000 USD) & $1.31 \mathrm{E}+05$ & $1.85 \mathrm{E}+05$ & 5050 & $8.10 \mathrm{E}+05$ \\
Distance (km) & 7405.84 & 3191.83 & 36.18 & 18190.62 \\
AVE tariff on imports & 0.05 & 0.07 & 0 & 0.18 \\
1 if regional trade agreement & 0.34 & 0.47 & 0 & 1 \\
1 if common primary language & 0.07 & 0.26 & 0 & 1 \\
1 if colonial relationship & 0.04 & 0.19 & 0 & 1 \\
& & & & \\
\hline
\end{tabular}

\footnotetext{
${ }^{14}$ EU27 imports only 5\% plantains in 2012 and 4\% in 2013 and the rest is banana (source: International Trade Centre).
} 


\subsection{Results}

Tables 3.3 and 3.4 present the estimation of gravity models for banana imports. As discussed above, we utilize two different measures of intensity of certification: (1) the number of producers accepted under the GlobalGAP certification process; (2) the number of hectares harvested under GlobalGAP certification. We argue that the number of certified producers is a better measure of intensity than actual number of certificates. This is primarily because certification could be obtained by farmers either individually (Options 1 and 2) or as group (Options 3 and 4). As a result, two countries with equal numbers of certificates do not necessarily reflect similar magnitudes of GlobalGAP penetration due to variation in the group size. In such cases, the number of producers accepted under the GlobalGAP certification process shows a better spread of GlobalGAP. Furthermore, landholding size differs among producers as well as among countries; other than the number of certified producers, another measure of intensity of certification could be landholding by the certified producer. This would capture heterogeneous effects of landholding under GlobalGAP certification.

Since the process of GlobalGAP adoption and diffusion is not entirely random, methodologically we have to contend with the possibility of GlobalGAP endogeneity. For example, existing trade relations between countries in a particular period could affect the import value of bananas through certification and also the other way round; endogeneity could arise due to such reverse causality between these variables. Resultantly, the estimated impact of GlobalGAP is likely to be biased. However, we argue that by taking certification variable in lag we could surpass the possibility of such reverse causality. Therefore, we additionally provide our estimation results with one period of lag in GlobalGAP certification. We argue that with a lagged measure of certification, reverse causality is likely to be absent.

Table 3.3 presents the gravity estimation of certified producers with and without lag. The first and second model report the estimation results for the random effects models with and without lag in the number of certified producers; meanwhile, the third and fourth models report similar estimations using the Mundlak approach. As the dependent and independent variables are all in logarithms, the estimated coefficients indicate the elasticities. 
Table 3.3 - Impact of Number of GlobalGAP Certified Producers on Value of Banana Imports

\begin{tabular}{|c|c|c|c|c|}
\hline \multirow[b]{2}{*}{ GlobalGAP producers } & \multicolumn{2}{|c|}{ Random Effect } & \multicolumn{2}{|c|}{ Mundlak } \\
\hline & $\begin{array}{c}0.242 * * * \\
(0.033)\end{array}$ & & $\begin{array}{c}0.019 * * \\
(0.009)\end{array}$ & \\
\hline GlobalGAP producers (lagged) & & $\begin{array}{c}0.308 * * * \\
(0.038)\end{array}$ & & $\begin{array}{c}0.054 * * * \\
(0.006)\end{array}$ \\
\hline Banana production (1000 USD) & $\begin{array}{c}1.209 * * * \\
(0.204)\end{array}$ & $\begin{array}{c}1.182 * * * \\
(0.205)\end{array}$ & $\begin{array}{c}2.761 * * * \\
(0.509)\end{array}$ & $\begin{array}{c}2.672 * * * \\
(0.513)\end{array}$ \\
\hline Banana consumption (1000 USD) & $\begin{array}{c}2.077 * * \\
(1.057)\end{array}$ & $\begin{array}{c}1.612 \\
(1.058)\end{array}$ & $\begin{array}{c}1.324 \\
(1.137)\end{array}$ & $\begin{array}{c}0.748 \\
(1.157)\end{array}$ \\
\hline Distance $(\mathrm{km})$ & $\begin{array}{c}-0.766^{* * * *} \\
(0.203)\end{array}$ & $\begin{array}{c}-0.775^{* * * *} \\
(0.205)\end{array}$ & $\begin{array}{c}-0.786^{* * * *} \\
(0.205)\end{array}$ & $\begin{array}{c}-0.776^{* * * *} \\
(0.208)\end{array}$ \\
\hline 1 if regional trade agreement & $\begin{array}{c}0.317 * * * \\
(0.050)\end{array}$ & $\begin{array}{c}0.334 * * * \\
(0.053)\end{array}$ & $\begin{array}{l}0.081 * \\
(0.044)\end{array}$ & $\begin{array}{c}0.096 * * \\
(0.048)\end{array}$ \\
\hline 1 if common official language & $\begin{array}{c}0.385 * * \\
(0.174)\end{array}$ & $\begin{array}{c}0.411 * * \\
(0.171)\end{array}$ & $\begin{array}{c}0.446^{* * * *} \\
(0.169)\end{array}$ & $\begin{array}{c}0.453 * * * \\
(0.169)\end{array}$ \\
\hline 1 if colonial relationship & $\begin{array}{c}0.319 \\
(0.285)\end{array}$ & $\begin{array}{c}0.263 \\
(0.278)\end{array}$ & $\begin{array}{c}0.179 \\
(0.261)\end{array}$ & $\begin{array}{c}0.172 \\
(0.260)\end{array}$ \\
\hline AVE tariff on imports & $\begin{array}{l}-0.398 \\
(0.354)\end{array}$ & $\begin{array}{l}-0.213 \\
(0.344)\end{array}$ & $\begin{array}{l}-0.225 \\
(1.051)\end{array}$ & $\begin{array}{c}0.945 \\
(1.128)\end{array}$ \\
\hline lremIMP & $\begin{array}{l}1.874^{*} \\
(1.058)\end{array}$ & $\begin{array}{c}1.391 \\
(1.059)\end{array}$ & $\begin{array}{c}1.378 \\
(1.141)\end{array}$ & $\begin{array}{c}0.824 \\
(1.159)\end{array}$ \\
\hline lremEXP & $\begin{array}{c}1.088^{* * * *} \\
(0.203)\end{array}$ & $\begin{array}{c}1.072 * * * \\
(0.204)\end{array}$ & $\begin{array}{c}2.801 * * * \\
(0.510)\end{array}$ & $\begin{array}{c}2.762 * * * \\
(0.514)\end{array}$ \\
\hline Constant & $\begin{array}{c}-85.967 * * \\
(34.190)\end{array}$ & $\begin{array}{c}-70.788 * * \\
(34.230)\end{array}$ & $\begin{array}{c}-82.509 * * \\
(37.078)\end{array}$ & $\begin{array}{c}-68.660 * \\
(37.676)\end{array}$ \\
\hline Observations & 5,940 & 3,942 & 5,940 & 3,942 \\
\hline Number of PAIR & 1,998 & 1,998 & 1,998 & 1,998 \\
\hline
\end{tabular}

Note: Robust standard errors are reported in the parentheses; all models include time fixed effects. *, ** and *** indicate the level of statistical significance at $10 \%, 5 \%$ and $1 \%$, respectively.

Looking at the RE models, we find that depending on the model specification, a $1 \%$ change in the number of certified producers increases the import value by $0.2 \%$ to $0.3 \%$. Thus the GlobalGAP intensity has an inelastic impact on EU banana imports. On the other hand, when estimated with the Mundlak approach, these elasticities decrease even further in magnitude. However, the significance of the coefficients of GlobalGAP producers across all models confirms the positive relationship between the GlobalGAP intensity and banana imports for all EU countries. Most of 
the standard gravity variables display the expected signs. For example, while longer distances affect trade negatively, countries with higher production capacities export more. Similarly, countries having regional trade agreements and using common languages trade more.

Table 3.4 - Impact of Hectares under GlobalGAP Certification on Value of Banana Imports

\begin{tabular}{|c|c|c|c|c|}
\hline \multirow[b]{2}{*}{ GlobalGAP area harvested (hectares) } & \multicolumn{2}{|c|}{ Random Effect } & \multicolumn{2}{|c|}{ Mundlak } \\
\hline & $\begin{array}{c}0.233 * * * \\
(0.020)\end{array}$ & & $\begin{array}{c}0.002 \\
(0.009)\end{array}$ & \\
\hline GlobalGAP area harvested (lagged hectares) & & $\begin{array}{c}0.253 * * * \\
(0.019)\end{array}$ & & $\begin{array}{c}0.024 * * * \\
(0.005)\end{array}$ \\
\hline Banana production (1000 USD) & $\begin{array}{c}1.015^{* * * *} \\
(0.199)\end{array}$ & $\begin{array}{c}0.998 * * * \\
(0.201)\end{array}$ & $\begin{array}{c}2.968 * * * \\
(0.558)\end{array}$ & $\begin{array}{c}2.989 * * * \\
(0.559)\end{array}$ \\
\hline Banana consumption (1000 USD) & $\begin{array}{c}2.066^{* * *} \\
(1.029)\end{array}$ & $\begin{array}{c}1.624 \\
(1.061)\end{array}$ & $\begin{array}{c}1.359 \\
(1.133)\end{array}$ & $\begin{array}{c}0.785 \\
(1.168)\end{array}$ \\
\hline Distance $(\mathrm{km})$ & $\begin{array}{c}-0.768 * * * * \\
(0.201)\end{array}$ & $\begin{array}{c}-0.780 * * * \\
(0.205)\end{array}$ & $\begin{array}{c}-0.797 * * * \\
(0.203)\end{array}$ & $\begin{array}{c}-0.788^{* * *} \\
(0.206)\end{array}$ \\
\hline 1 if regional trade agreement & $\begin{array}{c}0.139 * * * \\
(0.047)\end{array}$ & $\begin{array}{c}0.139 * * * \\
(0.050)\end{array}$ & $\begin{array}{l}-0.040 \\
(0.042)\end{array}$ & $\begin{array}{l}-0.038 \\
(0.047)\end{array}$ \\
\hline 1 if common official language & $\begin{array}{c}0.438^{* *} \\
(0.175)\end{array}$ & $\begin{array}{c}0.456 * * * \\
(0.174)\end{array}$ & $\begin{array}{c}0.496 * * * \\
(0.175)\end{array}$ & $\begin{array}{c}0.490 * * * \\
(0.175)\end{array}$ \\
\hline 1 if colonial relationship & $\begin{array}{c}0.255 \\
(0.275)\end{array}$ & $\begin{array}{c}0.205 \\
(0.271)\end{array}$ & $\begin{array}{c}0.104 \\
(0.267)\end{array}$ & $\begin{array}{c}0.108 \\
(0.265)\end{array}$ \\
\hline AVE tariff on imports & $\begin{array}{l}-0.441 \\
(0.336)\end{array}$ & $\begin{array}{l}-0.361 \\
(0.331)\end{array}$ & $\begin{array}{l}-0.350 \\
(1.052)\end{array}$ & $\begin{array}{c}0.528 \\
(1.117)\end{array}$ \\
\hline lremIMP & $\begin{array}{l}1.857^{*} \\
(1.030)\end{array}$ & $\begin{array}{c}1.400 \\
(1.061)\end{array}$ & $\begin{array}{c}1.413 \\
(1.138)\end{array}$ & $\begin{array}{c}0.861 \\
(1.172)\end{array}$ \\
\hline lremEXP & $\begin{array}{c}0.934 * * * \\
(0.198)\end{array}$ & $\begin{array}{c}0.921 * * * \\
(0.201)\end{array}$ & $\begin{array}{c}3.010 * * * \\
(0.559)\end{array}$ & $\begin{array}{c}3.059 * * * \\
(0.560)\end{array}$ \\
\hline Constant & $\begin{array}{c}-80.629 * * \\
(33.283)\end{array}$ & $\begin{array}{l}-66.305^{*} \\
(34.261)\end{array}$ & $\begin{array}{c}-78.158 * * \\
(36.367)\end{array}$ & $\begin{array}{l}-64.960 * \\
(37.418)\end{array}$ \\
\hline Observations & 5,940 & 3,942 & 5,940 & 3,942 \\
\hline Number of PAIR & 1,998 & 1,998 & 1,998 & 1,998 \\
\hline $\begin{array}{l}\text { Note: Robust standard errors are reported } \\
\text { indicate the level of statistical significance }\end{array}$ & $\begin{array}{l}\text { parenthese } \\
\%, 5 \% \text { and } 1\end{array}$ & $\begin{array}{l}\text { all models } \\
\text { respective }\end{array}$ & de time fix & $*, * *$ and \\
\hline
\end{tabular}


coefficient, but the negative impact of distance and positive impact of common language only survives for the EU27. Again, positive impact of regional trade agreements is observed only in the random effects models and vanishes in the Mundlak models.

\subsection{Conclusions}

This paper adds to the existing literature on private standards by analyzing the impact of GlobalGAP certification on banana trade intensity. GlobalGAP is an international standard that directs trade mostly to EU countries. Since private standards directly affect trade, even if adoption of GlobalGAP is voluntary in nature, its compliance could be quasi-mandatory for exporters competing in the international market.

With a three year panel data from 2010 to 2012, we use OLS estimation of the gravity trade model to understand the possible impact of GlobalGAP certification on banana exports to the EU. We use two measures of GlobalGAP certification intensity, namely, the number of certified producers and the number of hectares harvested under certified banana production. Methodologically, we recognize the issue of possible reverse causality of banana trade of GlobalGAP adoption and diffusion. However, such effects are likely to be absent if we take lagged value of GlobalGAP certification variables. We provide our estimation results for level as well as lagged GlobalGAP certification. Since we use a three year panel, only one year of lag in the certification could be used to tackle the reverse causality.

The first finding of the gravity estimation indicates a positive impact of GlobalGAP certification on the value of trade. Thus, GlobalGAP promotes banana exports to the EU. This result remains robust across all model specifications with and without lag in GlobalGAP at aggregated and disaggregated levels for EU countries. This suggests that the impact of GlobalGAP has been affecting banana imports for all EU countries in a similar fashion. 


\section{Conclusion}

The recent evolutions in regulatory practices due to new standards and certification schemes is one of the major factors affecting the pace and pattern of global trade. Private standards are playing an increasing role in the governance of agricultural and food supply chains (Henson, 2006). This motivates our current study to concentrate on the area of private food standards. Our study focuses on GlobalGAP, a well-known private standard of the agrifood sector. We address two main questions. First, analysis takes into account the country level determinates of worldwide spread of GlobalGAP. Second, we use a gravity trade model approach to examine the impact of GlobalGAP certification on banana imports of the European Union.

There is a large body literature on diffusion of standards, mostly focused on ISO standards. Studies with a focus on the agrifood sector are rare. Kleinwechter and Grethe (2006), Asfaw et al. (2009), and Kersting and Wollni (2012) have all studied GlobalGAP. These studies, however, analyze the adoption of GlobalGAP at the farm level for specific countries. On global diffusion of GlobalGAP, there is only one study, to our knowledge, by Herzfeld et al. (2011) which analyzes the adoption of BRC food and GlobalGAP standards. We use a panel for five years from 2008 to 2012 for 170 FAO member countries to analyze GlobalGAP diffusion in the agricultural sector as a whole as well as in the crops subsector. For estimation, a Heckman two-stage model is applied using the number of GlobalGAP certified producers as well as the number of hectares harvested under GlobalGAP as dependent variables.

In the area of impact analysis of policy regulation on trade, there is a wide range of literature available. The majority of these studies focus on regulations such as SPS, TBT and HACCP standards while some others consider the ISO standard. For example Otsuki et. al. (2001), Wilson and Otsuki (2004), Anders and Caswell (2009) Xiong and Beghin (2011) and Ferro et al. (2013). So far there is not a single study on the impact of GlobalGAP on international trade. We look at this case specifically by analyzing GlobalGAP certified banana imports of the EU. Our study considers a three year panel from 2010 to 2012 for 74 banana exporting countries.

Our gravity trade estimations show that compliance to GlobalGAP helps access export market in the EU. This study adds to the literature questioning the role of standards as barriers or facilitators of trade. At the same time, however, it is important to note that the benefits of adopting GlobalGAP certification are not equally available to farming communities in different 
countries. The reason is that the spread of the GlobalGAP certification scheme has been highly skewed around the globe.

The diffusion process can be observed at both the individual level and the country level. Decisions of an individual farmer are affected by various factors such as farm size and managerial skill. (e.g. Asfaw et al., 2009). Clearly, this study focuses only on the country level diffusion process. To include farm level characteristics of each country is beyond the scope of this study. For each country, coverage of GlobalGAP diffusion can be explained by various country level factors such as geographic preconditions, trade relations, colonial ties and the level of economic development and governance. For example, South Korea and North Korea naturally have quite similar geographic and historic conditions. However they differ, for instance, in their levels of economic development and governance. Following our model, the difference in GlobalGAP diffusion in these two countries can at least be partly attributed to the difference in their governance and economic development conditions ${ }^{15}$. Similarly, Afghanistan has a large proportion of arable land and agriculture has a substantial share in the country's GDP. However, the little diffusion of GlobalGAP certification can partially be explained by poor development and governance conditions ${ }^{16}$.

Trade relation is a very important factor of our discussion. West European countries including Belgium, France, Germany, Italy, the Netherlands and Spain have the highest number of GlobalGAP certificates (GlobalGAP, 2012). This region marks the main consumer market for imports of GlobalGAP certified products produced in other countries. In this way, a country trading a little with the EU will have a low probability of diffusion. On the other hand, a farmer in that country will have a small incentive to adopt the certification. Our analysis of GlobalGAP diffusion shows that commonality of language, colonial ties and trade relations support the diffusion process. On the other hand, we find through our gravity trade analysis that the existence of language commonality and colonial relations between country pairs has a positive impact on trade - a common finding of gravity estimations. Collectively, the language and colonial relationships facilitate both diffusion and trade. Another finding of our work is that trade relations

\footnotetext{
${ }^{15}$ For instance, in 2012, South Korea has 259 producers under the GlobalGAP certification process while North Korea has none.

${ }^{16}$ Afghanistan data for 2012: Agriculture, value added \% of GDP: $25 \%$; Arable land in hectares: 7,790,000; Number of producers under GlobalGAP certification process: zero (1 in 2011).
} 
positively affect the diffusion of GlobalGAP and, at the same time, the intensity of certification enhances exports. This finding has an additional policy implication. The two way connection between diffusion of certification and trade may be seen as a mechanism that reinforces retailersupplier relations within networks, consequently making the inclusion of new entrants harder.

Auditing mechanisms for a certification scheme are another important factor. In line with (Barrett et al., 2002), we find that domestic availability of auditing reduces the cost of compliance and hence encourages certification. This implies that in certain countries, where there is a number of pre-existing GlobalGAP certified farmers, the installation of a GlobalGAP auditing firm may further help diffusion of the scheme. Compliance costs include variable costs as well as fixed costs, which implies scale economies. In this context, various factors such as farm size and the existence of farmer cooperatives can be important. 


\section{Reference}

Abbott, K.W., Snidal, D. (2008). Strengthening International Regulation through "Transnational New Governance". In: Henson,S. and Humphrey, J. (2009): The Impact of Private Food Safety Standards on the Food Chain and on Public Standard-Setting Process. Codex Alimentarius Commission, Session 32nd session, FAO headquarters, Rome.

Acharya, U. H., Ray, S. (2000). ISO certification in Indian industries: A survey. Total Quality Management 11, 261-66.

Alänge, S., Jacobsson, S., Jaryehammar, A. (1998). Some aspects of an analytical framework for studying the diffusion of organizational innovations. Technol. Anal. Strat. Manage. 10, 322 .

Alburquerque, P., Bronnenberg, B.J. and Corbettt, C.J. (2007). A spatiotemporal analysis of the global diffusionof ISO 9000 and ISO 14000 certification. Management Science, 53, 451468.

Anders, S., Caswell, J.A. (2009). Standards-as-barriers versus standards-as-catalysts: assessing the impact of HACCP implementation on US seafood imports. Am. J. Agric. Econ. 91, 310321.

Anderson, J. E. (1979). A theoretical foundation for the gravity equation. The American Economic Review, 106-116.

Anderson, J.E., Van Wincoop, E. (2003). Gravity with gravitas: A solution to the border puzzle. American Economic Review (93),170-192.

Asfaw, S. Mithofer, D., Waibel, H. (2009). EU food safety standards, pesticide use and farmlevel productivity: the case of high-value crops in Kenya. Journal of Agricultural Economics, 60 (3) , pp. 645-667.

Asfaw, S., Mithofer, D., \& Waibel, H. (2010a). Agrifood supply chain, private-sector standards, and farmers' health: Evidence from Kenya. Agricultural Economics, 41(3-4), 251-263.

Asfaw, S., Mithöfer, D., Waibel, H. (2007). What impact are EU supermarket standards having on developing countries export of high-value horticultural products? Evidence from Kenya. In: Paper Presented at the 105th EAAE Seminar 'International Marketing and International Trade of Quality Food Products', Bologna, Italy.

Asfaw, S., Mithofer, D., Waibel, H. (2010b). What impact are EU supermarket standards having on developing countries' export of highvalue horticultural products? Evidence from Kenya. Journal of International Food \& Agribusiness Marketing, 22(3-4), 252-276.

Augier, P., Gasiorek, M., Lai Tong, C. (2005). The impact of rules of origin on trade flows. Economic Policy, 20(43), 567-624.

Baier, S. L., Bergstrand, J. H. (2009). A simple method for approximating international trade-cost effects using the gravity equation. Journal of International Economics, 77(1), 77-85.

Bain, C. (2010). Governing the Global Value Chain: GLOBALGAP and the Chilean Fresh Fruit Industry. Int. Jrnl. of Soc. of Agr. \& Food, Vol. 17, No. 1, pp. 1-23 
Bansal, P., Bogner, W. (2002). Deciding on ISO 14001: economics, institutions, and context. Long Range Planning, 35, pp. 269-290.

Bansal, P., Hunter, T. (2003). Strategic explanations for the early adoption of ISO 14001. Journal of Business Ethics, 46, pp. 289-299.

Barrientos, S., Dolan, C. (2006). Ethical Sourcing in the Global Food System. Earthscan, London.

Bergstrand, J.H. (1985). The Gravity Equation in International Trade: Some Microeconomic Foundations and Empirical Evidence, Review of Economics and Statistics 67(3):474-81.

Blind, K., Jungmittag, J. (2005). Trade and the impact of innovations and standards: the case of germany and the UK. Appl. Econ. 37 (12), 1385-1398.

Boiral, O. (2007). Corporate greening through ISO 14001: a rational myth? Organization Science, 18, pp. 127-146.

Boselie, D., van de Kop, P. (2005). Institutional and organisational change in agri-food systems in developing and transition countries: identifying opportunities for smallholders.

Regoverning Markets Global Issue Paper 2, Royal Tropical Institute, Amsterdam, the Netherlands.

Brenton, P., Manchin, M. (2002). Making the EU Trade Agreements Work. The Role of Rules of Origin. CEPS working document no 183, Brussels: Centre for European Policy Studies.

Busch, L., Thiagarajan, D., Hatanaka, M., Bain, C., Flores, L. and Frahm, M. (2005). The Relationship of Third-Party Certification (TPC) to Sanitary/Phytosanitary (SPS) Measures and the International Agri-Food Trade: Final Report, RAISE SPS Global Analytical Report 9, Washington: USAID.

Campbell, H., (2005). The rise and rise of EurepGAP: European (Re) invention of colonial food relations? Int. J. Sociol. Food Agric. 13, 6-19.

Casadesús, M., Karapetrovic, S. (2005). Has ISO 9000 lost some of its lustre: a longitudinal impact study. International Journal of Operations \& Production Management, 25, pp. 580596.

Chemnitz, C. (2007). The compliance process of food quality standards on primary producer level: A case study of the Eurepgap standard in the a drop of water in the Indian ocean? The Impact of GlobalGAP Certification 71 Moroccan tomato sector. Working Paper No.

81/2007. Berlin: Humboldt Universitat.

Chemnitz, C., Grethe, H., Kleinwechter, U. (2007). Quality standards for food products: A particular burden for small producers in developing countries? (No. 83/2007). Working Paper, Wirtschafts-und Sozialwissenschaften an der Landwirtschaftlich-Gärtnerischen Fakultät, Humboldt-Universität zu Berlin.

Corbett, C.J., Kirsch, D.A. (2001). International diffusion of ISO 14000 certification. Production and Operations Management, 10, pp. 327-342.

Darby, M., Karni, E. (1973). Free competition and the optimal amount of fraud. Journal of Law and Economics, 16, 67-88. 
Darnall N., Edwards D. (2006). Predicting the cost of environmental management system adoption: the role of capabilities, resources and ownership structure. Strategic Management Journal 27(4), 301-320.

Deardorff, A.(1998). Determinants of bilateral trade: Does gravity work in a neoclassical world? In: Frankel, J.A. (Ed.), The Regionalization of the World Economy, (Chapter I).

Dingworth, K. (2008). North-South Parity in Global Governance: The Affirmative Procedures of the Forest Stewardship Council, Global Governance 14.1: 53-71. In: Henson,S. and Humphrey, J. (2009): The Impact of Private Food Safety Standards on the Food Chain and on Public Standard-Setting Process. Codex Alimentarius Commission, Session 32nd session, FAO headquarters, Rome.

Dries, L., Swinnen, J.F.M. (2004). Foreign Direct Investment, Vertical Integration and Local Suppliers: Evidence from the Polish Dairy Sector. World Development 32, no. 9: 15251544.

European Commission (2013). Directorate-General for Agriculture and Rural Development, September 2013.

FAO (2011). Intergovernmental group on bananas and tropical fruits, Current situation and shortterm outlook, Fifth session, Yaoundé, Cameroun.

Ferrantino, M. (2006). Quantifying the Trade and Economic Effects of Non-Tariff Measures. OECD Trade Policy Working Papers, No. 28, OECD Publishing.

Ferro, E., Wilson, J. S., Otsuki, T. (2013). The effect of product standards on agricultural exports from developing countries. World Bank Policy Research Working Paper 6518

Fisher, J. C., Pry, R. H. (1972). A simple substitution model of technological change. Technological forecasting and social change, 3, 75-88.

Gavronski, I., Ferrer, G., \& Paiva, E. L. (2008). ISO 14001 certification in Brazil: motivations and benefits. Journal of Cleaner Production, 16(1), 87-94.

Gertler, M. S. (2001). Best practice? Geography, learning and the institutional limits to strong convergence. Journal of Economic Geography 1:5-26.

Gibbon, P. (2003). Value-Chain Governance, Public Regulation and Entry Barriers in the Global Fresh Fruit and Vegetable Chain into the EU. Development Policy Review 21, no 5: 615-25.

Giovannucci, D., Ponte, S., (2005). Standards as a new form of social contract? Sustainability initiatives in the coffee industry. Food Policy 30 (3), 284-301.

GlobalGAP (2011). GlobalGAP Annual Report 2011. GlobalGAP c/o FoodPLUS GmbH, Cologne, Germany.

GlobalGAP (2013). GlobalGAP: Who We Are. http://www.globalgap.org/uk_en/who-we-are/ (accessed on March 20, 2013).

Graffham, A., Karehu, E., \& MacGregor, J. (2009). Impact of GlobalGAP on smallscale vegetable growers in Kenya. Standard bearers: Horticultural exports and private standards in Africa. London, UK: Natural Resource Institute. 
Graffham, A., Karehu, E., Macgregor, J. (2007). Impact of EurepGAP on Small-Scale Vegetable Growers in Kenya, Fresh insights 6. London: international institute for environment and Development.

Greene, W.H. (2011). Econometric analysis. Prentice Hall; 7 edition (February 13, 2011).

GTZ (2010). GlobalGAP Smallholder QMS Set-up Guide: How to Establish a QMS in Your Group. Deutsche Gesellschaft für Technische Zusammenarbeit (GTZ), Eschborn.

Gulati, A., Minot, N., Delgado, C., Bora, S. (2007). Growth in high-value agriculture in Asia and the emergence of vertical links with farmers. In J. F. M. Swinnen (Ed.), Global Supply Chains, Standards and the Poor. Oxford, CABI publishing.

Havinga, T. (2008). Actors in private food regulation: Taking responsibility or passing the buck to someone else?. Work, 23, 25.

Head, K. (2003). Gravity for beginners. University of British Columbia, 2053.

Henson, S., Humphrey, J. (2010). Understanding the complexities of private standards in global agri-food chains as they impact developing countries. J. Dev. Stud. 46, 1628-1646.

Henson, S., Jaffee, S. (2008). Understanding developing country strategic responses to the enhancement of food safety standards. The World Economy, 31(4), 548-568.

Henson, S., Majowicz, S., Masakure, O., Sockett, P., Jones, A., Hart, R., Knowles, L. (2006). Consumer assessment of the safety of restaurants: the role of inspection notices and other information cues. Journal of food Safety, 26(4), 275-301.

Henson, S., Masakure, O., Cranfield, J. (2011). Do fresh produce exporters in sub-Saharan Africa benefit from globalgap certification? World Dev. 39 (3), 375-386.

Henson, S., Northen, J. (1998). Economic determinants of food safety controls in supply of retailer own-branded products in United Kingdom.Agribusiness, 14(2), 113-126.

Henson, S., Northen, J. (1998). Economic determinants of food safety controls in supply of retailer own-branded products in United Kingdom.Agribusiness, 14(2), 113-126.

Henson, S., Reardon, T. (2005). Private agri-food standards: Implications for food policy and the agri-food system. Food policy, 30(3), 241-253.

Henson,S., Humphrey, J. (2009). The Impact of Private Food Safety Standards on the Food Chain and on Public Standard-Setting Process. Codex Alimentarius Commission, Session 32nd session, FAO headquarters, Rome.

Herzfeld, T., Drescher, L.S., Grebitus, C. (2011). Cross-national adoption of private food quality standards. Food Policy 36, 401-411.

Hughes, A. (2000). Retailers, knowledges and changing commodity networks: The case of the cut flower trade. Geoforum 31:175-90.

Humphrey, J. (2008). Private standards, small farmers and donor policy: EUREPGAP in Kenya. Institute of Development Studies at the University of Sussex.

Humphrey, J. (2009). Private standards, small farmers and donor policy: EUREPGAP in Kenya. Institute of Development Studies at the University of Sussex. 
Jaffee, S. (2003). "From Challenge to Opportunity: Transforming Kenya's Fresh Vegetable Trade in the Context of Emerging Food Safety and Other Standards in Europe" Agricultural and Rural Development Discussion Paper, Washington D.C.: The World Bank.

Jaffee, S. and Henson, S.J. (2004) Standards and Agri-food Exports from Developing Countries: Rebalancing the Debate, World Bank. Policy Research Working Paper 3348, Washington DC: The World Bank

Jaffee, S., Meer, K.V.D., Henson, S., Haan, C.D., Sewadeh, M., Ignacio, L. (2005). Food Safety and Agricultural Health Standards: Challenges and Opportunities for Developing Countries. Poverty Reduction \& Economic Management Trade Unit and Agriculture and Rural Development Department, Report No. 31207, The World Bank, Washinton, DC.

Kariuki, I. M., Loy, J. P., Herzfeld, T. (2012). Farmgate private standards and price premium: Evidence from the GlobalGAP scheme in Kenya's French beans marketing. Agribusiness, $28(1), 42-53$.

Kersting, S., Wollni, M. (2012). New institutional arrangements and standard adoption: Evidence from small-scale fruit and vegetable farmers in Thailand. Food Policy 37(4): 452462.

Kinsey, J. (2003). Emerging Trends in the New Food Economy: Consumers, Firms and Science. Paper Presented at the Conference, Changing Dimensions of the Food Economy: Exploring the Policy Issues', The Hague. In: Henson,S. and Humphrey, J. (2009): The Impact of Private Food Safety Standards on the Food Chain and on Public Standard-Setting Process. Codex Alimentarius Commission, Session 32nd session, FAO headquarters, Rome.

Kleinwechter, U., Grethe, H. (2006). The adoption of the Eurepgap standard by mango exporters in Piura, Peru.

Kolk, A. (2000). The Economics of Environmental Management. Essex, UK: Prentice Hall/ Financial Times.

Leland, H.E. (1979). Quacks, lemons, and licensing: a theory of minimum quality standards. J. Polit. Economy 87 (6), 1328-1346.

Li, Y., Beghin, J.C. (2012). A meta-analysis of estimates of the impact of technical barriers to trade. J. Policy Model. 34 (3), 497-511.

MacGregor, J., Graffham, A. (2009). Standard Bearers. Horticultural Exports and Private Standards in Africa. International Institute for Environment and Development, London.

Maertens, M., \& Swinnen, J. F. (2009). Trade, standards, and poverty: Evidence from Senegal. World Development, 37(1), 161-178.

Maertens, M., Dries, L., Dedehouanou F.A., Swinnen, J.F.M. (2007). High-value Supply Chains, Food Standards and Rural Households in Developing Countries. In: Swinnen, J.F.M (ed) Global Supply Chains, Standards and the Poor, CABI publishing.

Martinez-Zarzoso, I., Nowak-Lehman, D., Vollmer, S. (2007). The log of Gravity Revisited", CeGE Discussion Paper 64, Göttingen University. 
Mausch, K., Mithöfer, D., Asfaw, S., Waibel, H. (2009). Export vegetable production in Kenya under the EurepGAP standard: Is large "more beautiful" than small? Journal of Food Distribution Research, 40(3), 115-129.

Melnyk, S.A., Sroufe, R.P., Calantone, R.L., Montabon, F.L. (2002). Assessing the effectiveness of US voluntary environmental programs: an empirical study. International Journal of Production Research, 40, pp. 1853- 1878.

Minten, B., Randrianarison, L., Swinnen, J. F.M. (2006). Global Retail Chains and Poor Farmers: Evidence from Madagascar. LICOS Discussion Papers no. 164, Leuven: LICOS.

Minten, B., Randrianarison, L., Swinnen, J.F.M., (2009). Global retail chains and poor farmers: evidence from Madagascar. World Dev. 37, 1728-1741.

Mitchell, L. (2008). Private standards and international trade. IATRC January Meeting. Washington DC.

Mundlak, Y. (1978). On the pooling of time series and cross section data. Econometrica, 46(1), 69-85.

Narrod, C., Roy, D., Okello, J., Avendano, B., Rich, K., Thorat, A. (2009). Public-private partnerships and collective action in high value fruit and vegetable supply chains. Food Policy 34 (1), 8-15.

Nelson, P. (1970). Information and consumer behaviour. Journal of Political Economy, 78(2), 311-329.

Neumayer, E. and Perkins, R. (2004). What explains the uneven takeup of ISO14001 at the global level? A panel data analysis. Environment, 36, pp. 823-839.

Neumayer, E., Perkins, R. (2005). Uneven geographies of organizational practice. explaining the cross-national transfer and adoption of ISO9000. Econ. Geography 81, 237-260.

Nishitani, K. (2010). Demand for ISO 14001 adoption in the global supply chain: an empirical analysis focusing on environmentally conscious markets. Resour. Energy Econ. 32 (3), 395407.

Okello, J. J. (2005). Compliance with international food safety standards: the case of green bean production in Kenyan family farm. Michigan: Department of Agricultural Economics, Michigan State University.

Olper, A., Raimondi, V. (2008). Market access asymmetry in food trade. Rev. World Econ. 144 (3), 509-537.

Otsuki, T., Wilson, J. S., Sewadeh, M. (2001). What price precaution? European harmonisation of aflatoxin regulations and African groundnut exports.European Review of Agricultural Economics, 28(3), 263-284.

Ouma, S. (2007). Implementing a QMS for EurepGAP Standard Certification Under Option 2: Lessons Learned from the Kenyan Pilot Project and a Way Forward.

Ouma, S. (2010). Global standards, local realities: Private agrifood governance and the restructuring of the Kenyan horticulture industry. Economic Geography, 86(2), 196-222. 
Perkins, R., Neumayer, E. (2010). Geographic variations in the early diffusion of corporate voluntary standards: comparing ISO 14001 and the Global Compact. Environment and planning A, 42 (2), 347-365.

Ponte, S. (2008). Greener than thou: the political economy of fish ecolabeling and its local manifestations in South Africa. World Dev. 36, 159-175.

Potoski, M., Prakash, A. (2004). Regulatory convergence in nongovernmental regimes: crossnational adoption of ISO 14001 certification. Journal of Politics, 66, pp. 885-905.

Prajogo, D., Tang, A. K., Lai, K. H. (2012). Do firms get what they want from ISO 14001 adoption?: an Australian perspective. Journal of Cleaner Production,33, 117-126.

Reardon, T., Barrett, C. B. (2000). Agroindustrialisation, globalization and international development: an overview of issues, patterns and determinants" Agricultural Economics 23: 195-205.

Reardon, T., Barrett, C.B., Berdegue, J.A., Swinnen, J.F.M., (2009). Agrifood industry transformation and small farmers in developing countries. World Development 37 (11), 1717-1727.

Reardon, T., Codron, J. M., Busch, L., Bingen, J., Harris, C. (2000). Global change in agrifood grades and standards: agribusiness strategic responses in developing countries. The International Food and Agribusiness Management Review, 2(3), 421-435.

Reardon, T., Codron, J.-M., Busch, L., Bingen, J., Harris, C. (2001). Global change in agrifood grades and standards: agribusiness strategic responses in developing countries. Int. Food Agribusiness Manage. Rev. 2, 421-435.

Reardon, T., Timmer, P., Berdegué, J. (2004). The Rapid Rise of Supermarkets in Developing Countries: Induced Organisational, Institutional, and Technological Change in Agrifood Systems. Electronic Journal of Agricultural and Development Economics (Vol. 1, No. 2), pp. $168-183$.

Rose, A. (2004). Which International Institution Promote International Trade",Review of Intentional Economics 13(4) Rural Sociol. 13, 15-24.

Ryan, B., Gross, N. C. (1943). The diffusion of hybrid seed corn in two Iowa communities. Rural sociology, 8(1), 15-24.

Santos Silva, J.M.C., Tenreyro, S. (2006). The Log of Gravity. Review of Economics and Statistics 88(4): 641-658

Smith, A. (2003). Power relations, industrial clusters, and regional transformations: PanEuropean integration and outward processing in the Slovak clothing industry. Economic

Sturgeon, T. J. (2003). What really goes on in Silicon Valley? Spatial clustering and dispersal in modular production networks. Journal of Economic Geography 3:199-225.

Swann, G.P. (2010). International standards and trade: a review of the empirical literature. In: OECD Trade Policy Working Papers, No. 97.

Swinnen, J. F. (Ed.). (2007). Global supply chains, standards and the poor: how the globalization of food systems and standards affects rural development and poverty. Cabi. 
Swinnen, J.F.M. (2005). The Dynamics of Vertical Coordination in Agrifood Chains in Eastern Europe and Central Asia. Washington D.C. The World Bank.

Terziovski, M., Power, D., Sohal, A. (2003). The longitudinal effects of the ISO 9000 certification process on business performance. European Journal of Operational Research, 143 , pp. 580-595.

Terziovski, M., Power, D., Sohal, A. (2003). The longitudinal effects of the ISO 9000 certification process on business performance. European Journal of Operational Research, 143 , pp. 580-595.

Thiagarajan, D., Busch, L., Frahm, M. (2005). The relationship of third party certification (TPC) to sanitary/phytosanitary (SPS) measures and the international agrifood trade. Case study: EUREPGAP. Washington, DC: USAID.

Tinbergen, J. (1963). Shaping the World Economy. The International Executive, 5(1), 27-30.

True, J., Mintrom, M. (2001). Transnational networks and policy diffusion: The case of gender mainstreaming. International Studies Quarterly 45:27-57.

UNCTAD (2007) Challenges and Opportunities arising from private Standards on Food safety and Environment for Exporters of Fresh Fruit and Vegetables in Asia: Experiences of Malaysia, Thailand and Viet Nam, Geneva: United Nations Conference on Trade and Development

Viadiu, F.M., Fa, M.C., Saizarbitoria, I.H. (2006). ISO 9000 and ISO 14000 standards: an international diffusion model. Int. J. Operat. Prod. Manag. 26 (2), 141-165.

Von Braun, J. (2003). Presidential address: agricultural economics and distributional effects. In: International Association of Agricultural Economists (Ed.), 25thConference of the International Association of Agricultural Economists. Blackwell Publishing, Durban, South Africa, pp. 1-20.

Vorley, B., Fox, T. (2004). Global Food Chains - Constraints and Opportunities for Smallholders. Report Prepared for the OECD DAC POVNET Agriculture and Pro- Poor Growth Task Team Helsinki Workshop 17-18 June 2004.

Wei, G., Huang, J., Yang, J. (2012). The impacts of food safety standards on China's tea exports. China Economic Review 23 (2012) 253-264

Wilson, J., \& Otsuki, T. (2004). To spray or not to spray: Pesticides, banana exports, and food safety. Food Policy, 29, 131-146.

World Bank (2005). Food Safety and Agricultural Health Standards: Challenges and Opportunities for Developing Country Exports, Report 31207, Washington D.C. The World Bank, Poverty Reduction and Economic Management Trade Unit.

Xiong, B., Beghin, J. C. (2011). Disentangling the demand-enhancing effect and trade-cost effect of technical measures in agricultural trade among OECD countries. In 2011 Annual Meeting, July 24-26, 2011, Pittsburgh, Pennsylvania. Agricultural and Applied Economics Association. 


\section{Appendix 1}

GlobalGAP Certification across Agriculture Subsectors (GlobalGAP, 2011)

\begin{tabular}{l|lr} 
Bananas & 243,400 \\
Potatoes & 243,100 \\
Grapes & 237,800 \\
Apples & 198,500 \\
Oranges & 159,200 \\
Peaches & 136,800 \\
Pears & & 102,400 \\
Nectarines & 76,600 \\
Mandarins & & 60,600 \\
Pineapples & & 60,600
\end{tabular}




\section{Appendix 2}

Distribution of GlobalGAP Certification across Countries

\section{GlobalGAP coverage in hecatres}
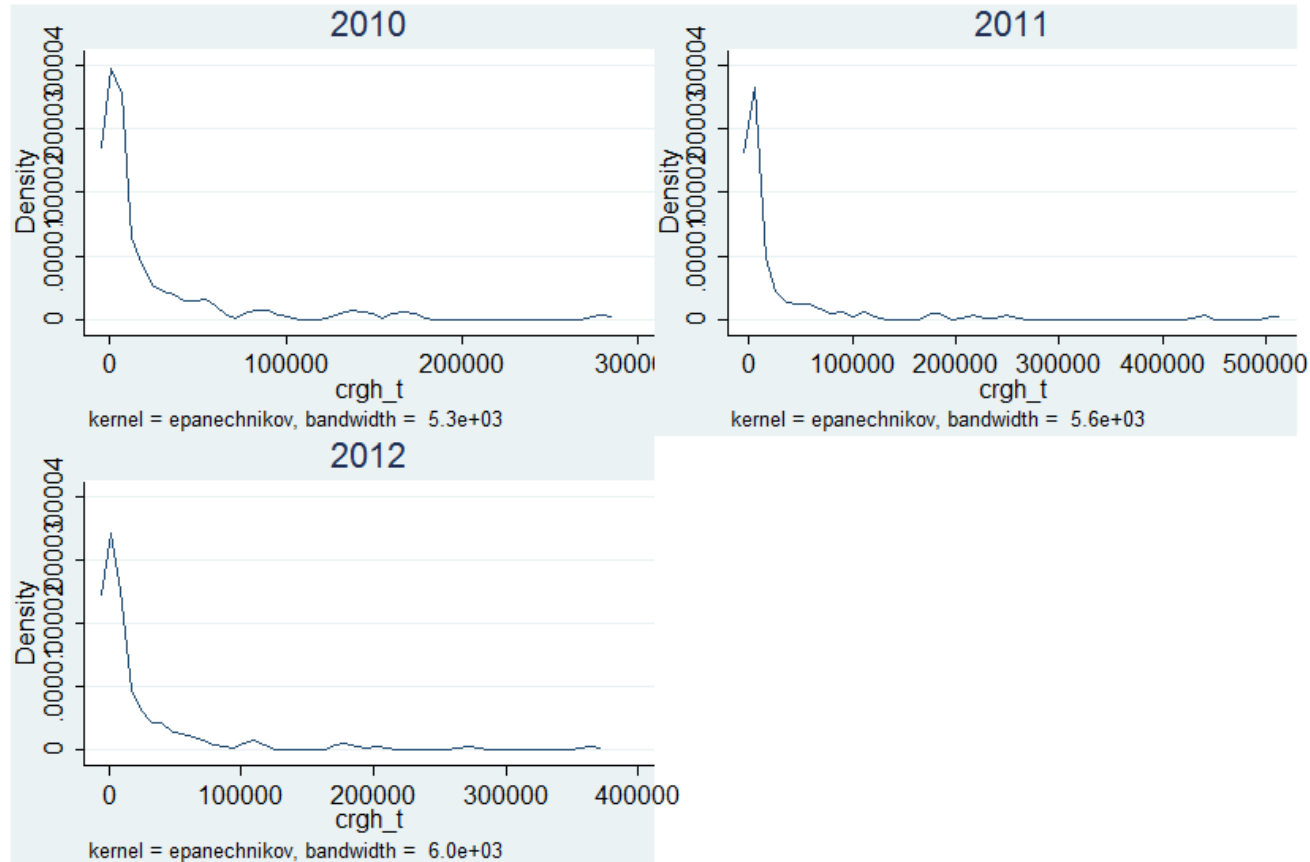


\section{Appendix 3}

\section{Welfare Analysis of Exports of GlobalGAP Certified Banana in GTAP Framework}

In the previous section, the gravity estimation shows a positive impact of GlobalGAP certification on banana exports to the EU. The welfare change attributed to the enhanced exports can be analyzed using the GTAP framework. This would need the following steps.

\section{Data mapping}

In the GTAP Database 8, there are 129 regions and 57 GTAP commodities. In the database, there only exists a vegetables \& fruit ( $v_{-}$f) sector, and not a standalone sector for bananas. We are therefore required to create a 'banana sector' in the model. GTAPAgg is the default tool for aggregation and disaggregation of data. An alternative tool is the Dynamic Steering System (DSS) tool of MAGNET. In this regard, the social accounting matrix (SAM) can be a tool to check for post-split balance. Coding this split in the GEMPACK will split the default vegetables $\&$ fruit sector into two components: a banana sector and a vegetables $\&$ fruit (less banana) sector. An illustration of the split in SAM showing a row entry 'Imports' and a column entry 'Activity' is given below. Let $b$ be the share of banana, and then $1-b$ is the vegetable and fruit sector, without banana.

\begin{tabular}{|c|c|c|c|}
\hline & \multicolumn{2}{|c|}{ Activity } \\
\hline & & $\mathrm{v}_{-} \mathrm{f}$ & banana \\
\hline \multirow{2}{*}{$\begin{array}{l}\text { 号 } \\
\text { :्ञ }\end{array}$} & $v_{-} f$ & $\mathrm{~V}_{\mathrm{o}}(1-\mathrm{b})(1-\mathrm{b})$ & $V_{o}(1-b)(b)$ \\
\hline & Banana & $V_{o}(b)(1-b)$ & $\mathrm{V}_{\mathrm{o}}(\mathrm{b})(\mathrm{b})$ \\
\hline
\end{tabular}

In order to state the SAM balance algebraically,

$$
\begin{aligned}
& \mathrm{V}=\left[\mathrm{V}_{\mathrm{o}}(1-\mathrm{b})(1-\mathrm{b})\right]+\left[\mathrm{V}_{\mathrm{o}}(1-\mathrm{b})(\mathrm{b})\right]+\left[\mathrm{V}_{\mathrm{o}}(\mathrm{b})(1-\mathrm{b})\right]+\left[\mathrm{V}_{\mathrm{o}}(\mathrm{b})(\mathrm{b})\right] \\
& \mathrm{V}=\mathrm{V}_{\mathrm{o}}(1) ; \text { Where } \mathrm{V}_{\mathrm{o}} \text { is the original SAM value and } \mathrm{V} \text { is the value after split. }
\end{aligned}
$$




\section{Calculation of Tariff Equivalent of GlobalGAP}

The gravity trade model estimates the impact of the intensity of GlobalGAP certification in the

exporting country on exports of that country to the EU. A tariff equivalent of GlobalGAP can be estimated, as a subsidy or negative tax in our case, using value of the gravity coefficient given the value of elasticity of substitution between goods is known.

\section{AVE implementation into model}

A pioneering work to this end is Andriamananjara, Ferrantino, Tsigas (2003), where these various options are explored in a CGE model for different sectors of the economy. Similarly, Fugazza and Maur (2008) focused on various treatments of NTBs in GTAP modeling while grouping regulations into rent creating and technical NTBs. The AVE of GlobalGAP can be treated in the same way as NTBs. A tariff equivalent can be implemented into a CGE model as an efficiency impediment, export tax, or import tariff. In GTAP coding terms:

a) $a m s_{\text {irs }}=$ Percentage change in effective price of good $i$ from region $r$ to region $s$ due to change in unobserved trade cost

b) $t m s_{i r s}=$ Percentage change in the tax on imports of good $i$ from region $r$ to region $s$

c) $t x s_{\text {irs }}=$ Percentage change in the tax on exports of good $i$ from region $r$ to region $s$

The observed trade value includes the impact of GlobalGAP. This impact can be isolated by a reversal from the baseline scenario. This can be done, for instance, by an export tax shock equivalent to GlobalGAP. This would, however, unnecessarily generate a rent for the government account in the exporting country. An alternative to this can be a negative technical efficiency shock. This is to model an inefficient managerial decision to grow bananas without certification.

After the shock, the model estimates the welfare change in terms of an equivalent variation. 